\title{
Novel mixed NOP/opioid receptor peptide agonists
}

Salvatore Pacifico ${ }^{1}$, Valentina Albanese ${ }^{1}$, Davide Illuminati ${ }^{1}$, Erika Marzola ${ }^{1}$, Martina Fabbri ${ }^{1}$,

Federica Ferrari ${ }^{2}$, Victor A.D. Holanda ${ }^{2}$, Chiara Sturaro $^{2}$, Davide Malfacini ${ }^{3}$, Chiara Ruzza ${ }^{2} 4^{*}$, Claudio Trapella ${ }^{1,4}$, Delia Preti ${ }^{1 *}$, Ettore Lo Cascio $^{5}$, Alessandro Arcovito ${ }^{5,6}$, Stefano Della Longa ${ }^{7 *}$, Martina Marangoni ${ }^{8}$, Davide Fattori ${ }^{8}$, Romina Nassini ${ }^{8}$, Girolamo Calò ${ }^{3}$, and Remo Guerrini ${ }^{1,4}$.

${ }^{1}$ Department of Chemical, Pharmaceutical and Agricultural Sciences, University of Ferrara, Via Luigi Borsari 46, 44121 Ferrara, Italy.

${ }^{2}$ Department of Neuroscience and Rehabilitation, Section of Pharmacology, University of Ferrara, Via Fossato di Mortara 17/19, 44121 Ferrara, Italy.

${ }^{3}$ Department of Pharmaceutical and Pharmacological Sciences, University of Padova, Largo Meneghetti 2, 35131 Padova, Italy

${ }^{4}$ Technopole of Ferrara, LTTA Laboratory for Advanced Therapies, via Fossato di Mortara 70, 44121 Ferrara, Italy.

${ }^{5}$ Dipartimento di Scienze Biotecnologiche di Base, Cliniche Intensivologiche e Perioperatorie, Università Cattolica del Sacro Cuore, Largo F. Vito 1, 00168 Roma, Italy.

${ }^{6}$ Fondazione Policlinico Universitario A. Gemelli IRCCS, Largo F. Vito 1, 00168 Roma, Italy.

${ }^{7}$ Department of Life, Health and Environmental Sciences, University of L'Aquila, Pza S. Tommasi 1, 67100 L'Aquila, Italy

${ }^{8}$ Department of Health Sciences, Section of Clinical Pharmacology and Oncology, University of Florence, Viale Pieraccini, 6, 50139, Florence, Italy

\section{CONTENTS}

\begin{tabular}{|l|c|}
\hline & Pag. \\
\hline Scheme S1. Synthesis of Fmoc-2',6'-dimethyltyrosine & S2 \\
\hline Synthetic procedures for the preparation of Fmoc-2',6'-dimethyltyrosine & $\mathrm{S} 3-\mathrm{S} 5$ \\
\hline Table S1.Structures of non-proteinogenic amino acids & $\mathrm{S} 6$ \\
\hline HPLC chromatograms and ESI mass spectra of the final peptide derivatives & $\mathrm{S} 7-\mathrm{S} 41$ \\
\hline Model set-up of non-natural peptides for MD & $\mathrm{S} 42$ \\
\hline Model set-up of the mu receptor & $\mathrm{S} 42$ \\
\hline Model set-up of the peptide-mu receptor complexes & $\mathrm{S} 42$ \\
\hline Analysis of molecular dynamics trajectories & $\mathrm{S} 43$ \\
\hline Figures S1-S3 & $\mathrm{S} 44-\mathrm{S} 46$ \\
\hline References & $\mathrm{S} 47$ \\
\hline
\end{tabular}




\section{CHEMISTRY}

Scheme S1. Synthesis of Fmoc-2',6'-dimethyl-tyrosine developed in analogy to what previously published by Wang et $a l .{ }^{1}$

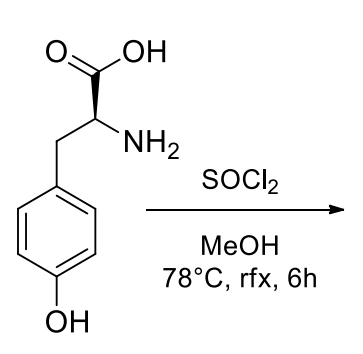

1<smiles>COC(=O)[C@H](N)Cc1ccc(O)cc1</smiles>

2<smiles>COC(=O)[C@H](N)Cc1ccc(O[Si](C)(C)C(C)(C)C)cc1</smiles>

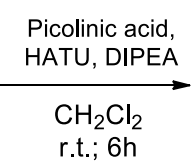<smiles>COC(=O)[C@H](Cc1ccc(O[Si](C)(C)C(C)(C)C)cc1)NC(=O)c1ccccn1</smiles><smiles>COC(=O)[C@H](Cc1c(C)cc(O[Si](C)(C)C(C)(C)C)cc1C)NC(=O)c1ccccn1</smiles><smiles>Cc1cc(O)cc(C)c1C[C@H](NC(=O)OCC1c2ccccc2-c2ccccc21)C(=O)O</smiles> 


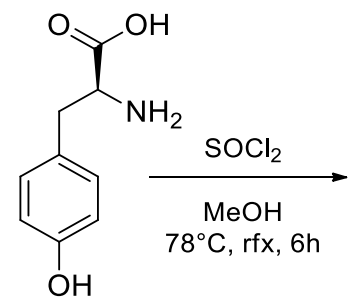

1<smiles>COC(=O)[C@H](N)Cc1ccc(O)cc1</smiles>

2
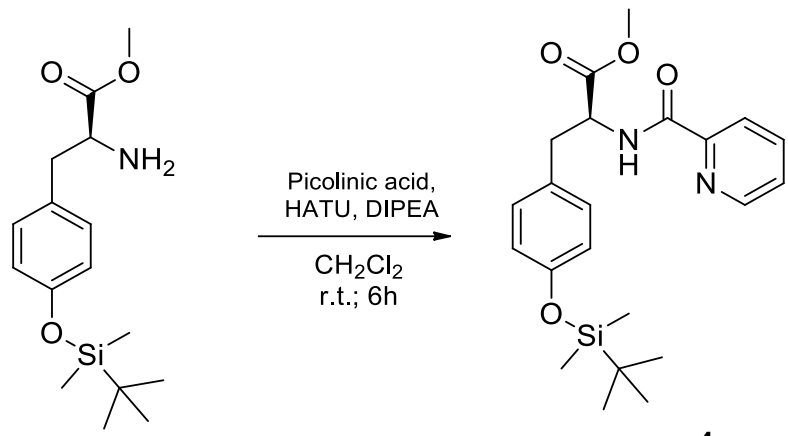

3

4

To a suspension of (S)-Tyrosine $1(16.56 \mathrm{mmol})$ in $\mathrm{MeOH}(30 \mathrm{~mL}), \mathrm{SOCl}_{2}(1.1 \mathrm{eq} ; 18.21 \mathrm{mmol})$ was added dropwise at $0{ }^{\circ} \mathrm{C}$ and the resulting mixture was heated at reflux and left stirring overnight. After the removal of the solvent, the methyl ester derivative $\mathbf{2}$ was obtained as a white powder that was used in the next step without further purifications (the structure was confirmed by ESI mass analysis of the crude product). The hydrochloride salt 2 was suspended in $\mathrm{CH}_{2} \mathrm{Cl}_{2}(90 \mathrm{~mL})$ then imidazole (1.2 eq; $\left.19.87 \mathrm{mmol}\right)$ and tertbutyldimethylsilyl chloride (1.2 eq; $19.87 \mathrm{mmol}$ ) were added to the mixture that was stirred at r.t. overnight. Once completed, the reaction was quenched with sat. $\mathrm{NaHCO}_{3}(30 \mathrm{~mL})$, the organic phase was isolated in a separatory funnel and the aqueous phase was further extracted with $\mathrm{CH}_{2} \mathrm{Cl}_{2}(2 \times 20 \mathrm{~mL})$. The organic layers were dried over $\mathrm{Na}_{2} \mathrm{SO}_{4}$, filtered, and concentrated under vacuum. Compound $\mathbf{3}$ was obtained as a yellowish oil which was used in the next step without further purifications. To a solution of $\mathbf{3}$ ( $1 \mathrm{eq} ; 16.56 \mathrm{mmol})$ in $\mathrm{CH}_{2} \mathrm{Cl}_{2}(90 \mathrm{~mL})$, HATU (1.2 eq; $19.87 \mathrm{mmol}$ ), DIPEA (2.5 eq; $41.39 \mathrm{mmol}$ ) and Picolinic acid (1.2 eq; 19.87 mmol) were added. The reaction was stirred at r.t. overnight. The mixture was quenched with $\mathrm{NH}_{4} \mathrm{Cl}(30 \mathrm{~mL})$, the organic phase was isolated in a separatory funnel and the aqueous phase was further extracted with $\mathrm{CH}_{2} \mathrm{Cl}_{2}$ $(2 \times 20 \mathrm{~mL})$. After drying over anhydrous $\mathrm{Na}_{2} \mathrm{SO}_{4}$, the solvent was removed under vacuum. The crude product was purified via flash column chromatography (AcOEt/Petroleum ether 3,5: 6,5) to obtain $\mathbf{4}$ as a white powder (Yield of 3 steps $83 \%$ ).

${ }^{1}$ H NMR (400 MHz, Chloroform- $d$ ): $\delta 8.58-8.56(\mathrm{~m}, 1 \mathrm{H}), 8.54(\mathrm{~d}, J=8.4 \mathrm{~Hz}, 1 \mathrm{H}), 8.11(\mathrm{dt}, J=7.8,1.1 \mathrm{~Hz}$, 1H), $7.82(\mathrm{td}, J=7.7,1.7 \mathrm{~Hz}, 1 \mathrm{H}), 7.44-7.41(\mathrm{~m}, 1 \mathrm{H}), 6.49$ (s, 2H), 4.94 (q, $J=8.1 \mathrm{~Hz}, 1 \mathrm{H}), 3.65(\mathrm{~s}, 3 \mathrm{H})$, $3.19-3.15(\mathrm{~m}, 2 \mathrm{H}), 0.96(\mathrm{~s}, 9 \mathrm{H}), 0.16(\mathrm{~s}, 6 \mathrm{H}) . \mathrm{MS}(\mathrm{ESI}):[\mathrm{M}+\mathrm{H}]^{+} 415.43 . \mathrm{T}_{\mathrm{R}}: 25.12 \mathrm{~min}$. 

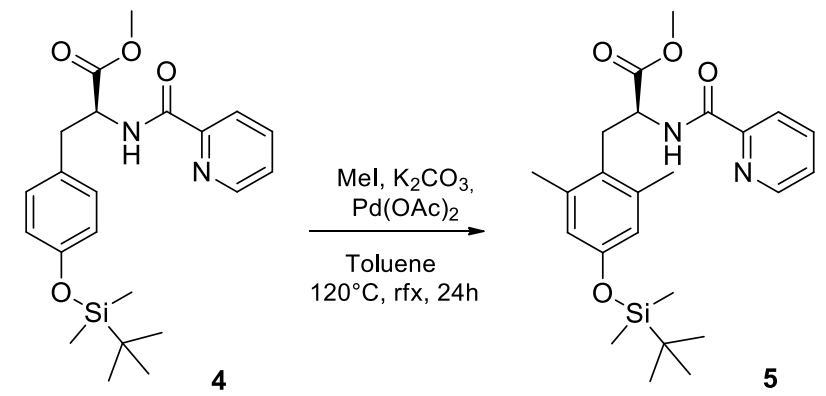

The picolinamido derivative 4 ( 1 eq; $13.74 \mathrm{mmol}$ ) was solubilized in toluene $(60 \mathrm{~mL})$ then $\mathrm{K}_{2} \mathrm{CO}_{3}(3 \mathrm{eq} ; 41.23$ mmol), $\mathrm{CH}_{3} \mathrm{I}(5 \mathrm{eq} ; 68.71 \mathrm{mmol})$ and $\mathrm{Pd}(\mathrm{OAc})_{2}(0.1 \mathrm{eq} ; 1.37 \mathrm{mmol})$ were added and the mixture was left stirring at $120{ }^{\circ} \mathrm{C}$ for $24 \mathrm{~h}$. The crude mixture was filtered through a celite pad, the filtrate was concentrated under vacuum and purified by flash column chromatography (AcOEt/Petroleum ether 3:7) affording $\mathbf{5}$ as an orange amorphous solid (Yield: 72\%).

${ }^{1}$ H NMR (400 MHz, Chloroform- $d$ ): $\delta 8.58-8.56(\mathrm{~m}, 1 \mathrm{H}), 8.54(\mathrm{~d}, J=8.5 \mathrm{~Hz}, 1 \mathrm{H}), 8.11(\mathrm{dt}, J=7.8,1.1 \mathrm{~Hz}$, 1H), $7.82(\mathrm{td}, J=7.7,1.7 \mathrm{~Hz}, 1 \mathrm{H}), 7.42(\mathrm{ddd}, J=7.6,4.8,1.2 \mathrm{~Hz}, 1 \mathrm{H}), 6.49(\mathrm{~s}, 2 \mathrm{H}), 4.94(\mathrm{q}, J=8.1 \mathrm{~Hz}, 1 \mathrm{H})$, $3.65(\mathrm{~s}, 3 \mathrm{H}), 3.18-3.16(\mathrm{~m}, 2 \mathrm{H}), 2.35-2.33(\mathrm{~m}, 6 \mathrm{H}), 0.95(\mathrm{~s}, 9 \mathrm{H}), 0.15(\mathrm{~s}, 6 \mathrm{H})$. MS (ESI): $[\mathrm{M}+\mathrm{H}]^{+} 443.31$ $\mathrm{T}_{\mathrm{R}}: 24.12 \mathrm{~min}$. 

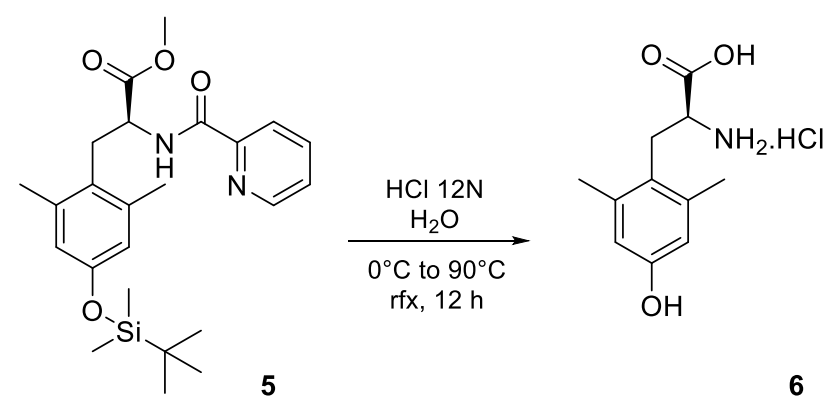

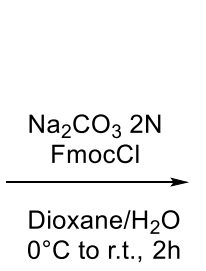

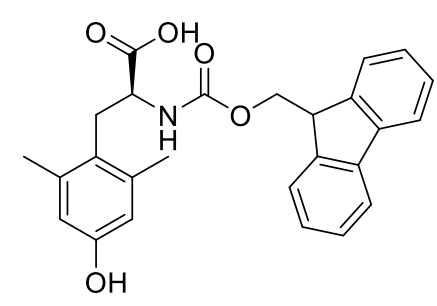

7

The picolinamido derivative 5 (1 eq; $9.89 \mathrm{mmol})$ was deprotected by adding $6 \mathrm{~N} \mathrm{HCl}(28 \mathrm{ml} ; 168 \mathrm{mmol})$ and refluxing the mixture for $12 \mathrm{~h}$. After this time, the reaction was cooled at r.t. and concentrated under vacuum to afford a crude residue that was directly used for the next step. Compound $\mathbf{6}$ was suspended in a mixture of water/dioxane 1:2 (20 mL: $40 \mathrm{~mL}$ ) and $\mathrm{Na}_{2} \mathrm{CO}_{3}$ (3 eq; $29.59 \mathrm{mmol}$ ) was added to reach $\mathrm{pH} 10$. Finally, FmocCl ( 0.9 eq; $8,87 \mathrm{mmol})$ was added at $0^{\circ} \mathrm{C}$. The reaction was left stirring at r.t. for $2 \mathrm{~h}$ and monitored via TLC (AcOEt/Petroleum ether 7:3 + 1\% Acetic acid). Once the reaction was completed, the solvents were concentrated to half volume under vacuum and $1 \mathrm{~N} \mathrm{HCl}$ was added at $0{ }^{\circ} \mathrm{C}$ until reaching $\mathrm{pH} 1-2$. The aqueous phase was extracted with AcOEt $(3 \times 20 \mathrm{~mL})$ and the organic layers were dried over $\mathrm{Na}_{2} \mathrm{SO}_{4}$, concentrated, and the crude residue was purified by flash chromatography (AcOEt/Petroleum ether 7:3 + 1\% Acetic acid). Compound 7 was obtained as a white powder (Yield: $72 \%$ ).

${ }^{1}$ H NMR (400 MHz, DMSO- $\left.d_{6}\right): \delta 12.63(\mathrm{~s}, 1 \mathrm{H}), 8.95(\mathrm{~s}, 1 \mathrm{H}), 7.89(\mathrm{~d}, J=7.6 \mathrm{~Hz}, 2 \mathrm{H}), 7.77(\mathrm{~d}, J=8.6 \mathrm{~Hz}$, $1 \mathrm{H}), 7.70-7.67(\mathrm{~m}, 2 \mathrm{H}), 7.41(\mathrm{td}, J=7.6,3.0 \mathrm{~Hz}, 2 \mathrm{H}), 7.32(\mathrm{q}, J=7.3 \mathrm{~Hz}, 2 \mathrm{H}), 6.38(\mathrm{~s}, 2 \mathrm{H}), 4.20-4.17(\mathrm{~m}$, 2H), $4.12-4.05(\mathrm{~m}, 1 \mathrm{H}), 3.33(\mathrm{bs}, 2 \mathrm{H}), 3.03-2.98(\mathrm{~m}, 1 \mathrm{H}), 2.86-2.80(\mathrm{~m}, 1 \mathrm{H}), 2.20(\mathrm{~s}, 6 \mathrm{H}) .{ }^{13} \mathbf{C} \mathbf{~ N M R}$ (DMSO- $d_{6}$ ): $\delta$ 173.70, 155.90, 155.10, 143.83, 143.75, 140.68, 137.77, 127.63, 127.05, 125.31, 125.11, 120.10, 114.82, 65.68, 54.29, 46.57, 30.71, 20.04. MS (ESI): [M+H] $]^{+} 431.13 . \mathrm{T}_{\mathrm{R}}: 19.38 \mathrm{~min}$. 
Table S1.Structures of non-proteinogenic amino acids
Abbreviation
Chemical Structure
Abbreviation
Chemical Structure

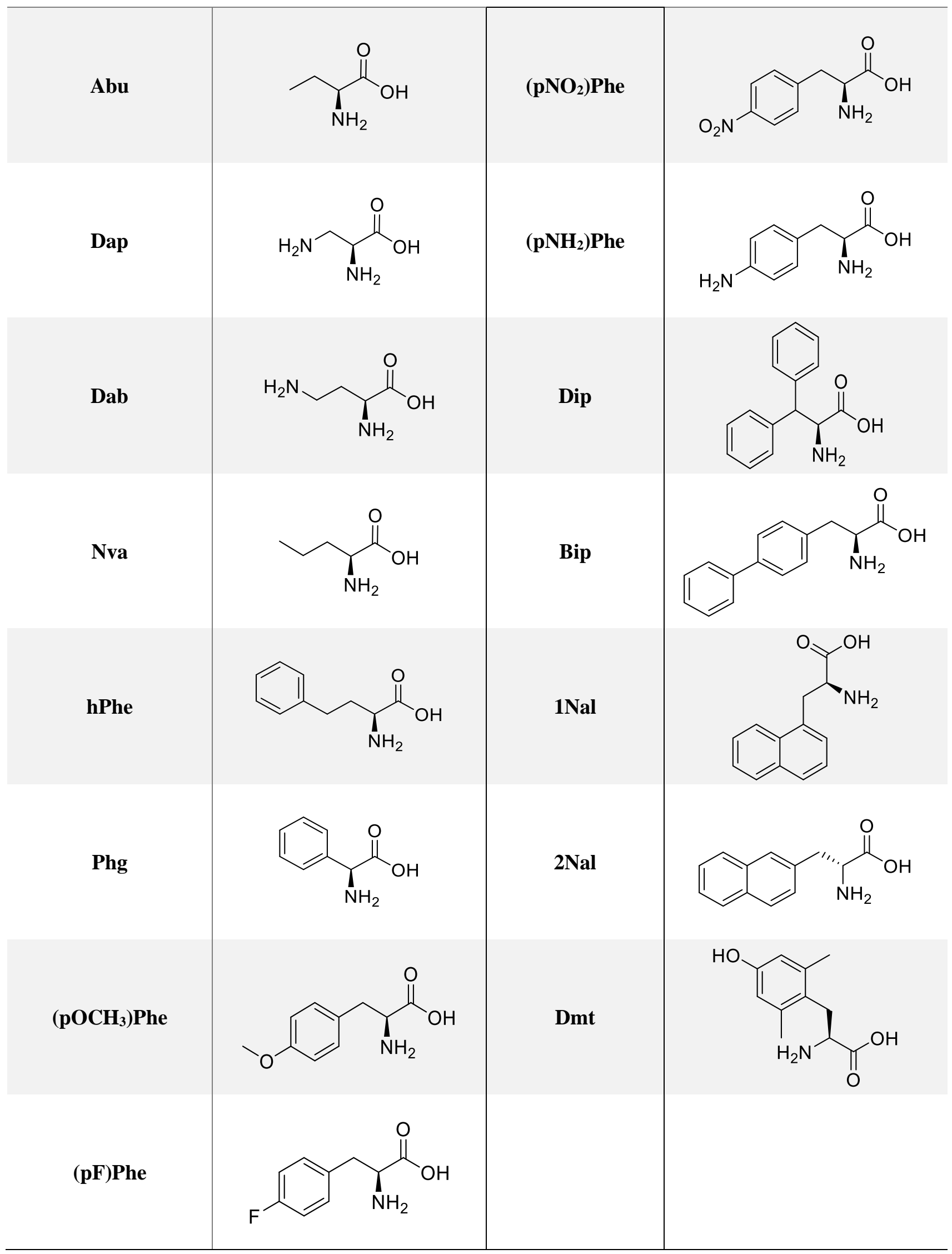


N/OFQ(1-13)NH
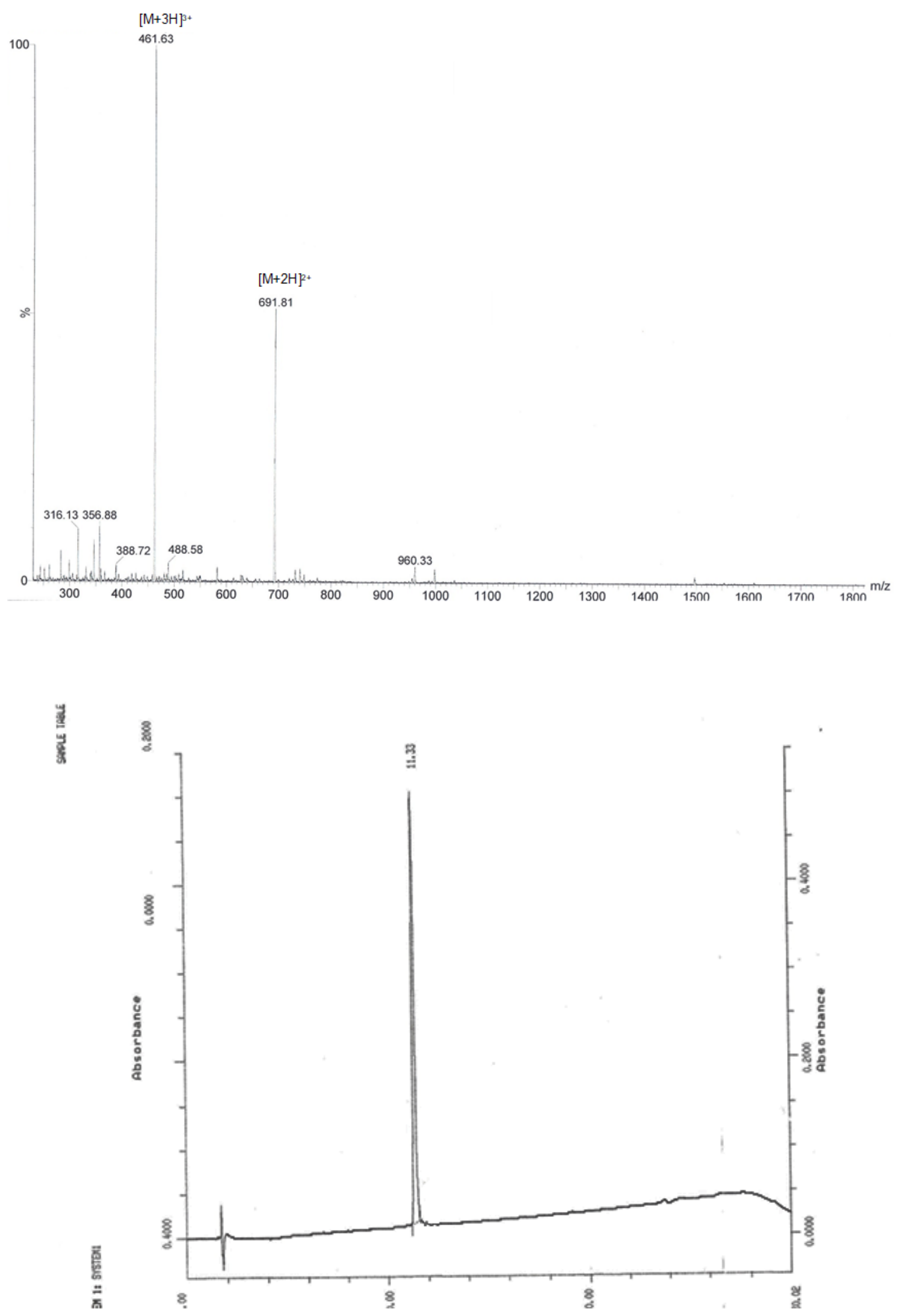


\section{$\left[\mathrm{Tyr}^{1}\right] \mathrm{N} / \mathrm{OFQ}(1-13) \mathrm{NH}_{2}$}

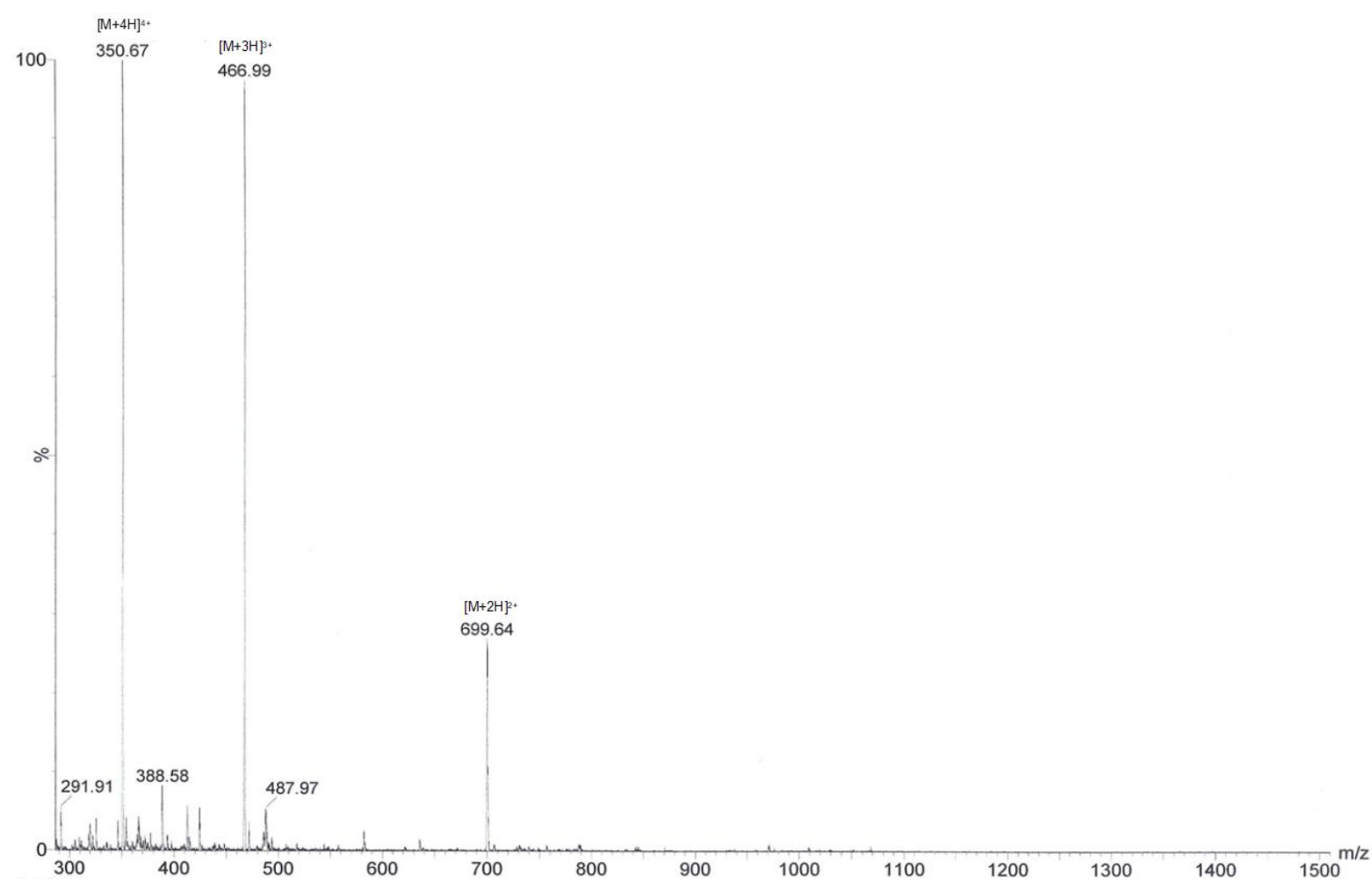

웡

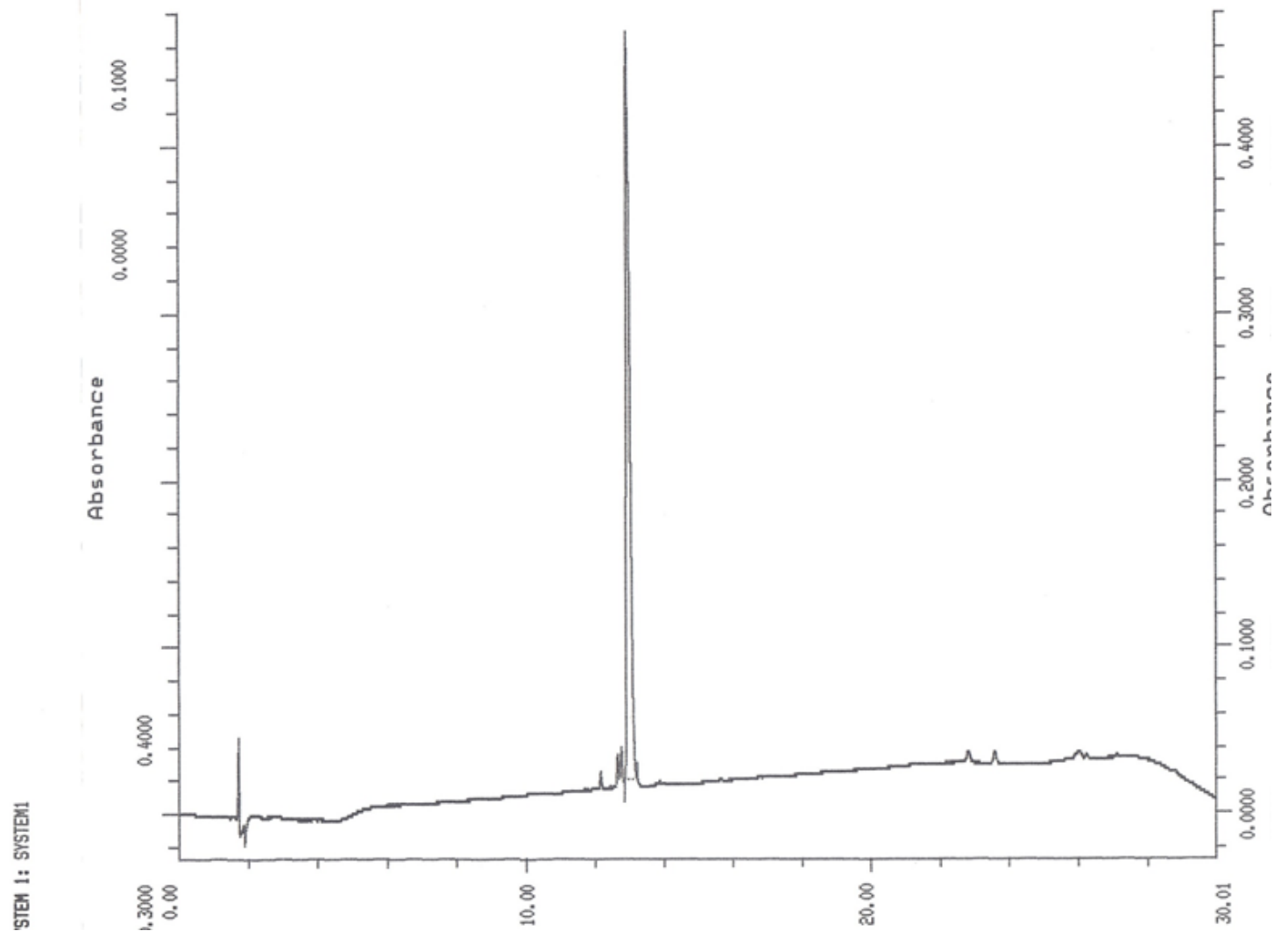




\section{$\left[\mathrm{Dmt}^{1}\right] \mathrm{N} / \mathrm{OFQ}(\mathbf{1 - 1 3}) \mathrm{NH}_{2}$}

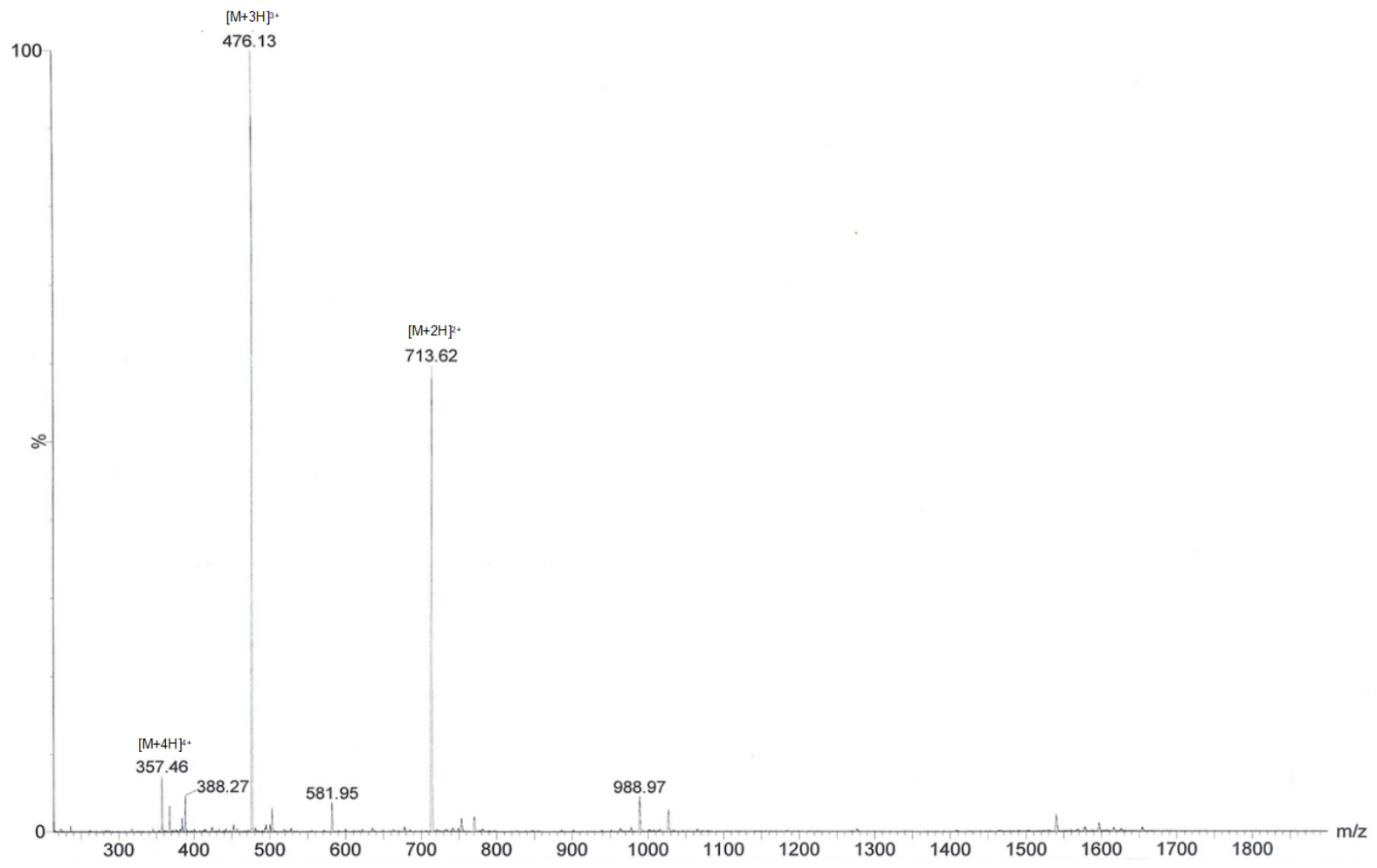

잉

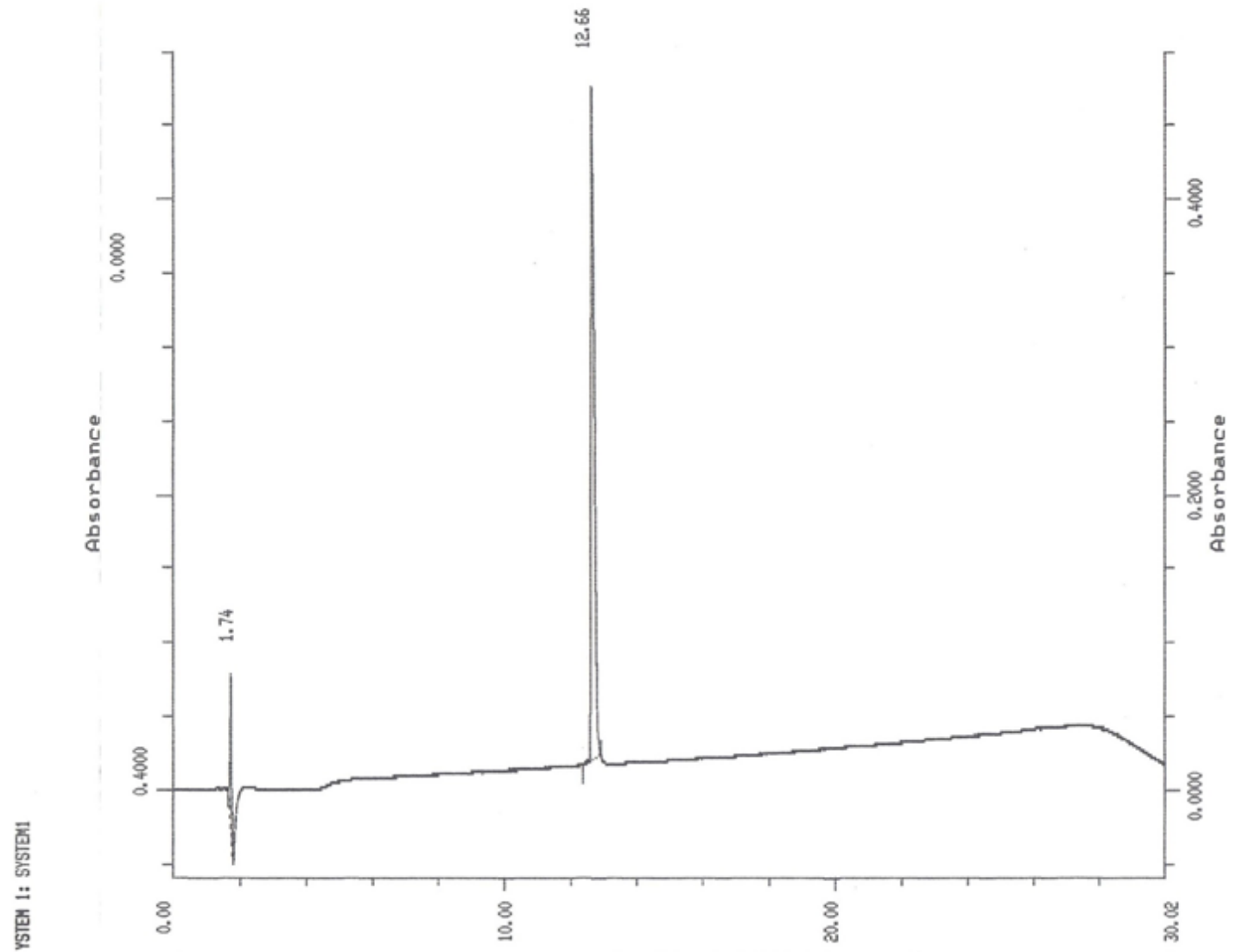




\section{$\left[\mathrm{Dmt}^{1}{ }^{1} \mathrm{Tyr}^{5}\right] \mathrm{N} / \mathrm{OFQ}(1-13) \mathrm{NH}_{2}$}

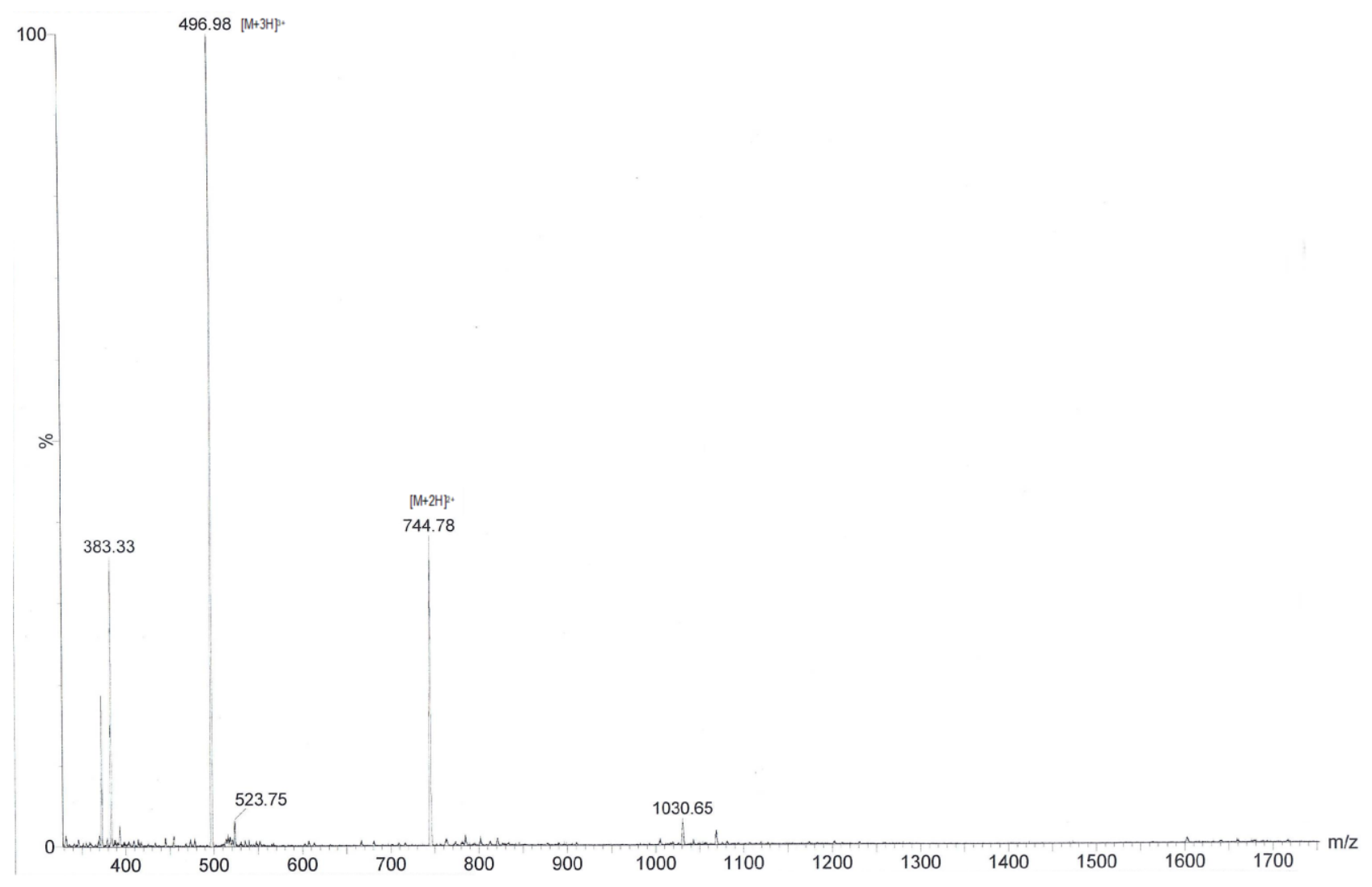

繥

$\stackrel{8}{9}$

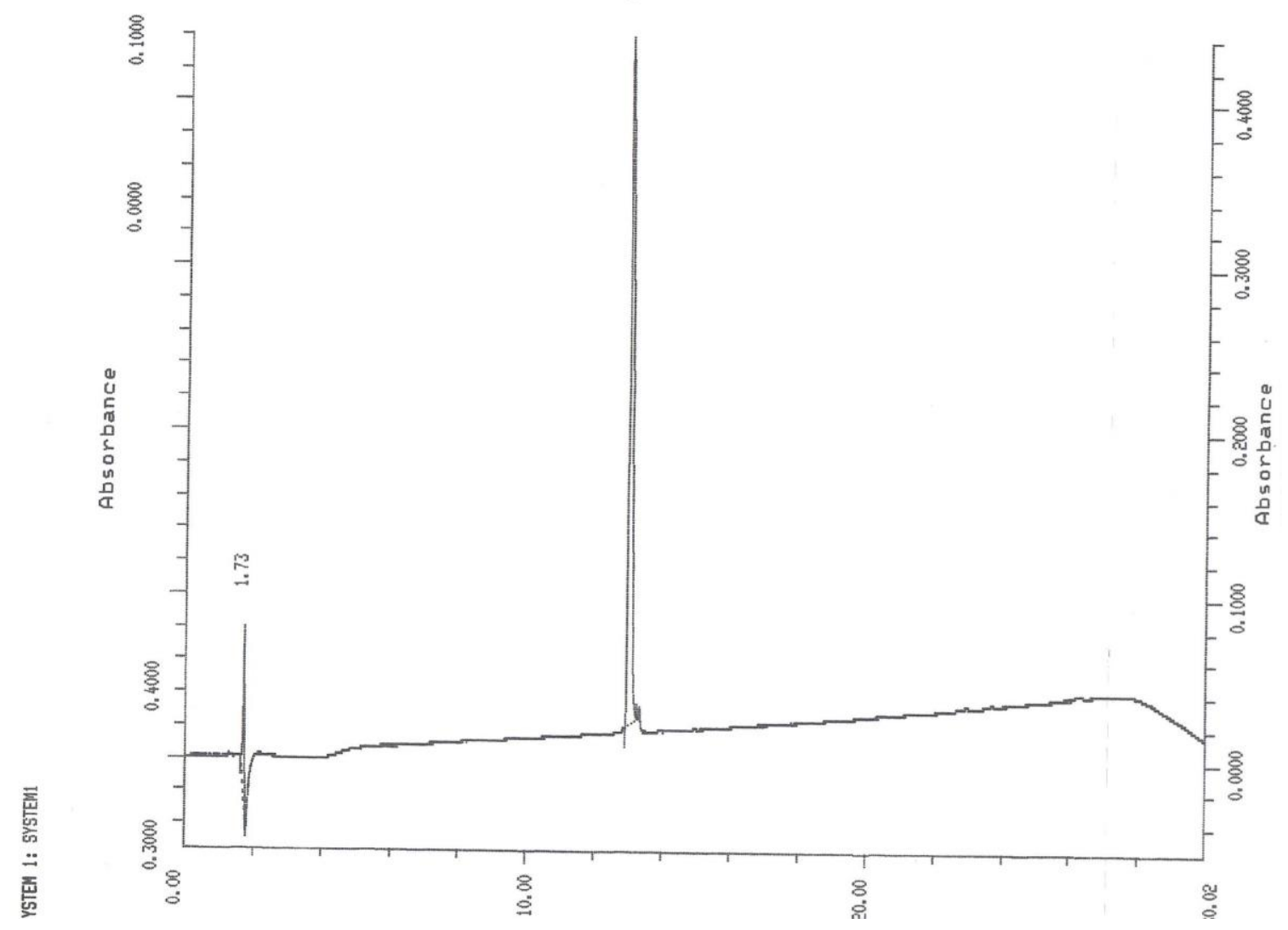




\section{Dermorphin}
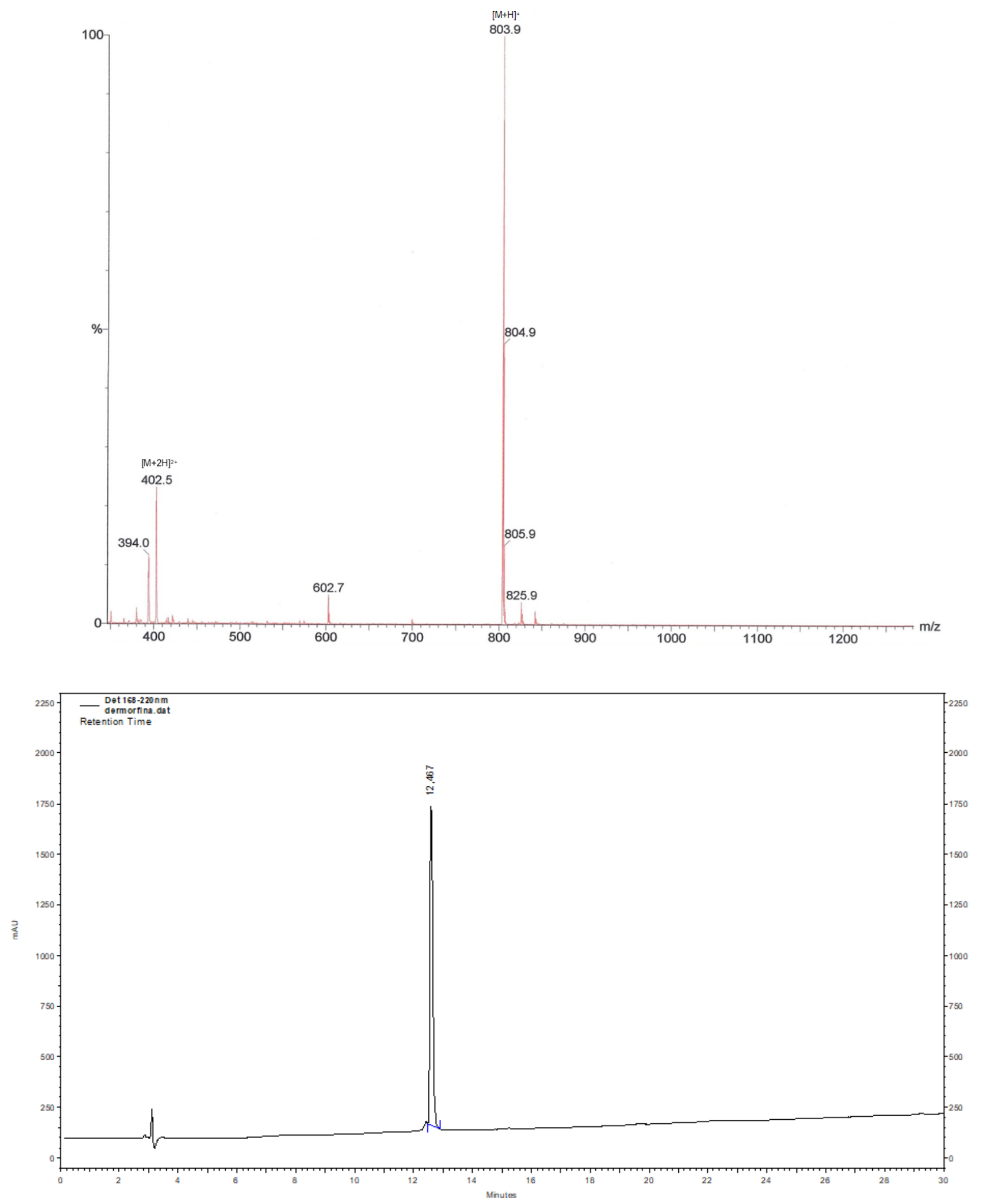


\section{$\left[\operatorname{Tyr}^{1} \operatorname{Asn}^{5}\right] \mathrm{N} / \mathrm{OFQ}(1-13) \mathrm{NH}_{2}$}
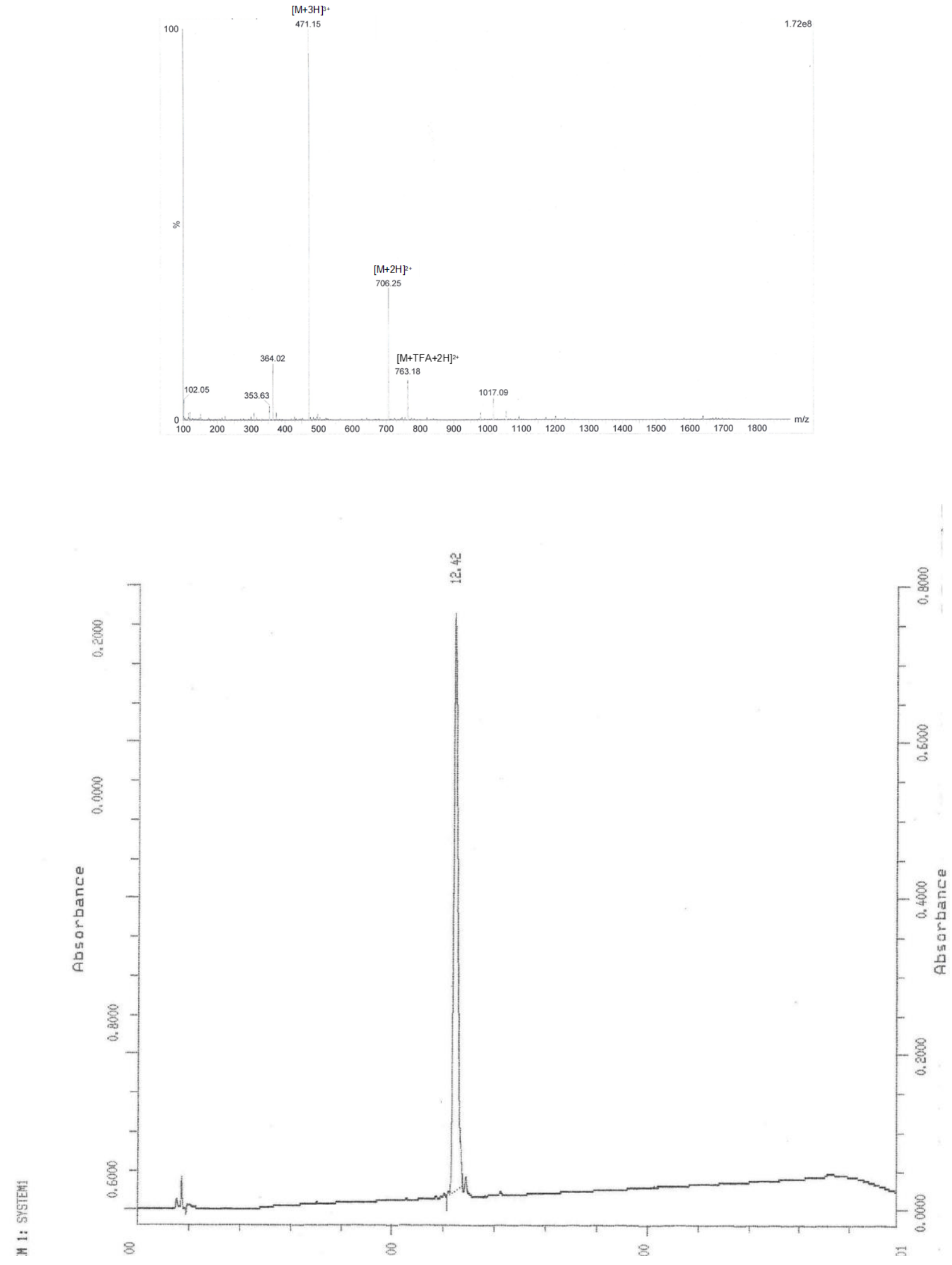
$\left[\mathrm{Tyr}^{1} \mathrm{Val}^{5}\right] \mathrm{N} / \mathrm{OFQ}(1-13) \mathrm{NH}_{2}$
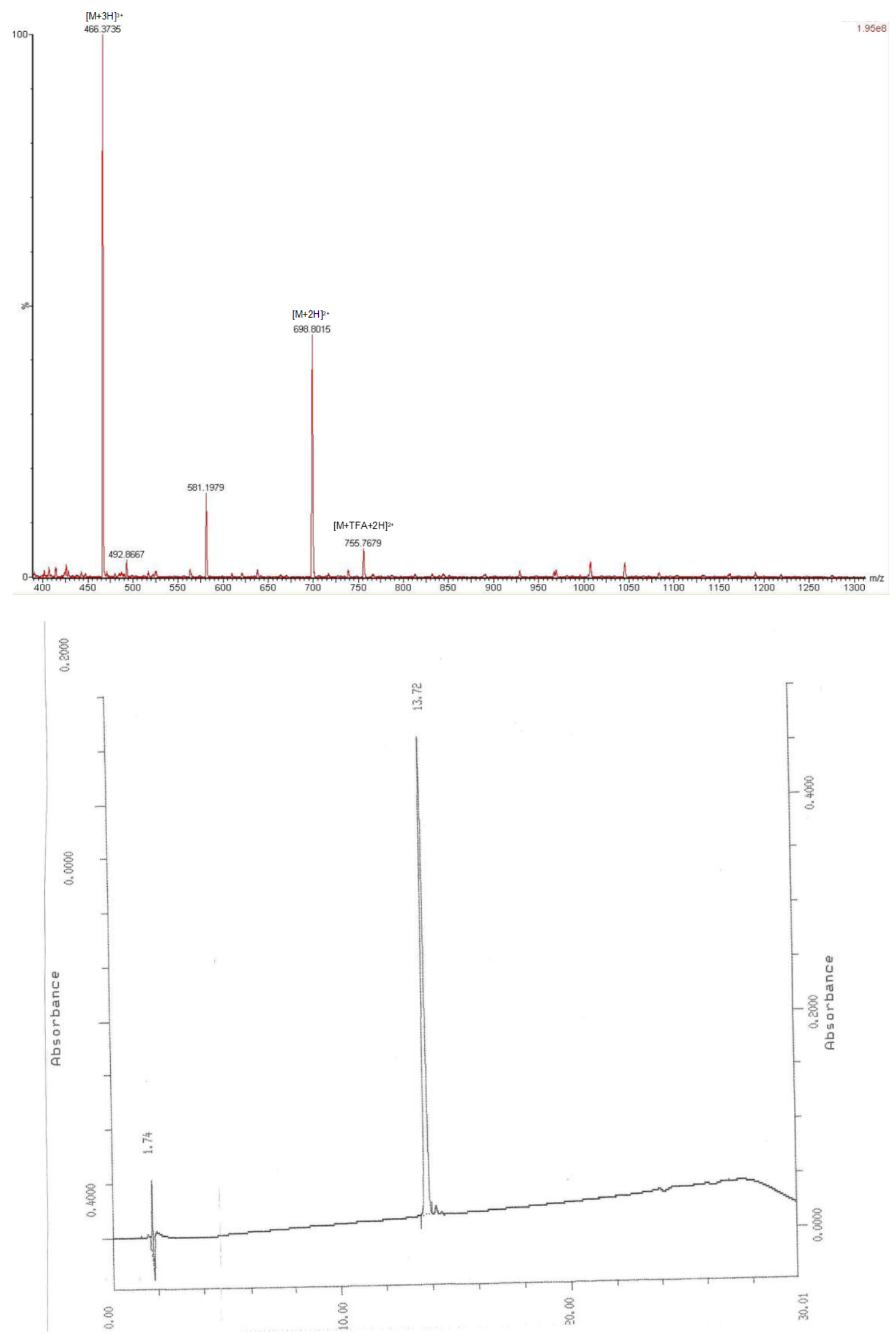
$\left[\operatorname{Tyr}^{1}, \operatorname{Lys}(\mathrm{Ac})^{5}\right] \mathrm{N} / \mathrm{OFQ}(1-13) \mathrm{NH}_{2}$
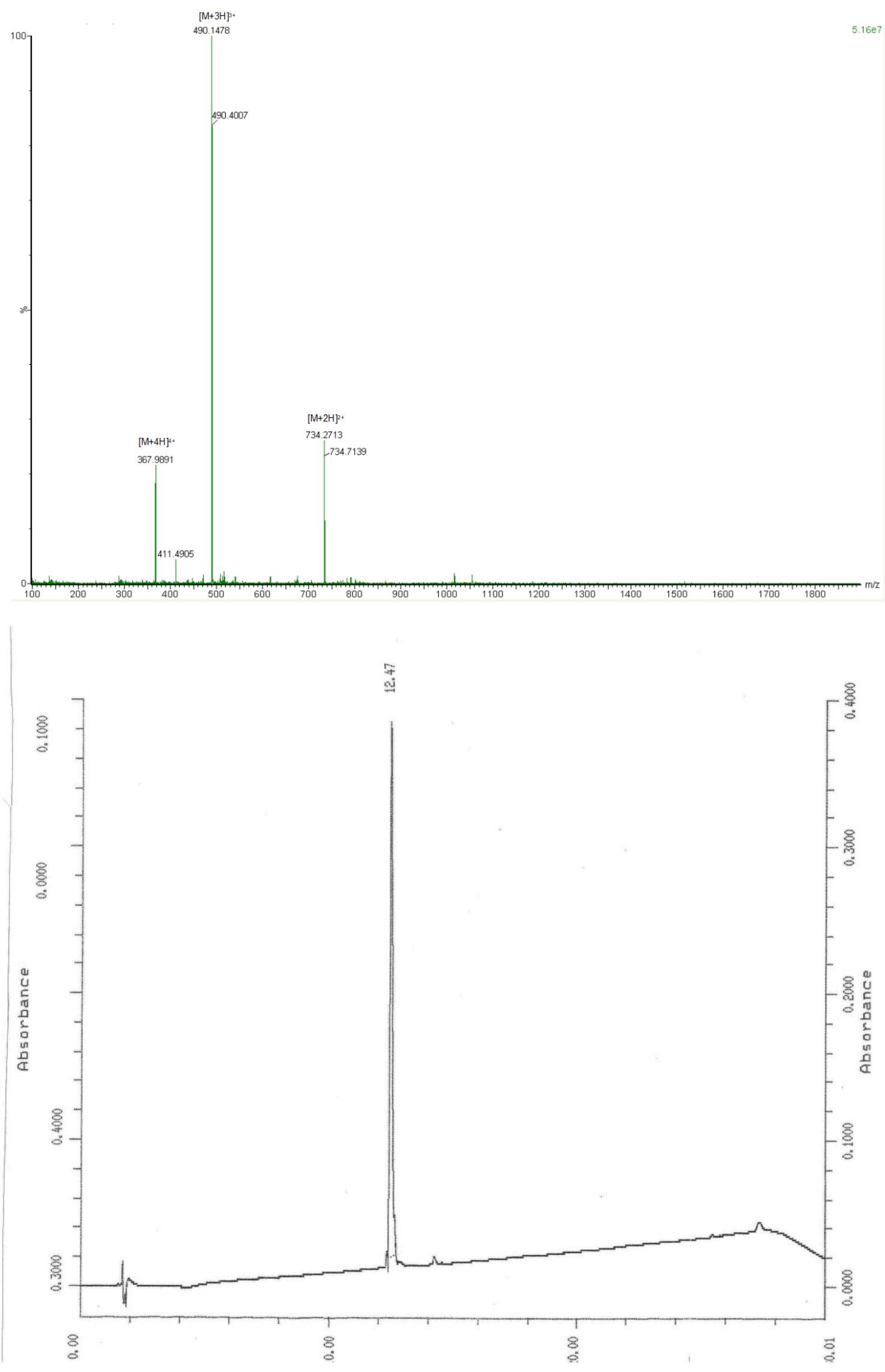
$\left[\mathrm{Tyr}^{1}, \mathrm{Abu}^{5}\right] \mathrm{N} / \mathrm{OFQ}(1-13) \mathrm{NH}_{2}$

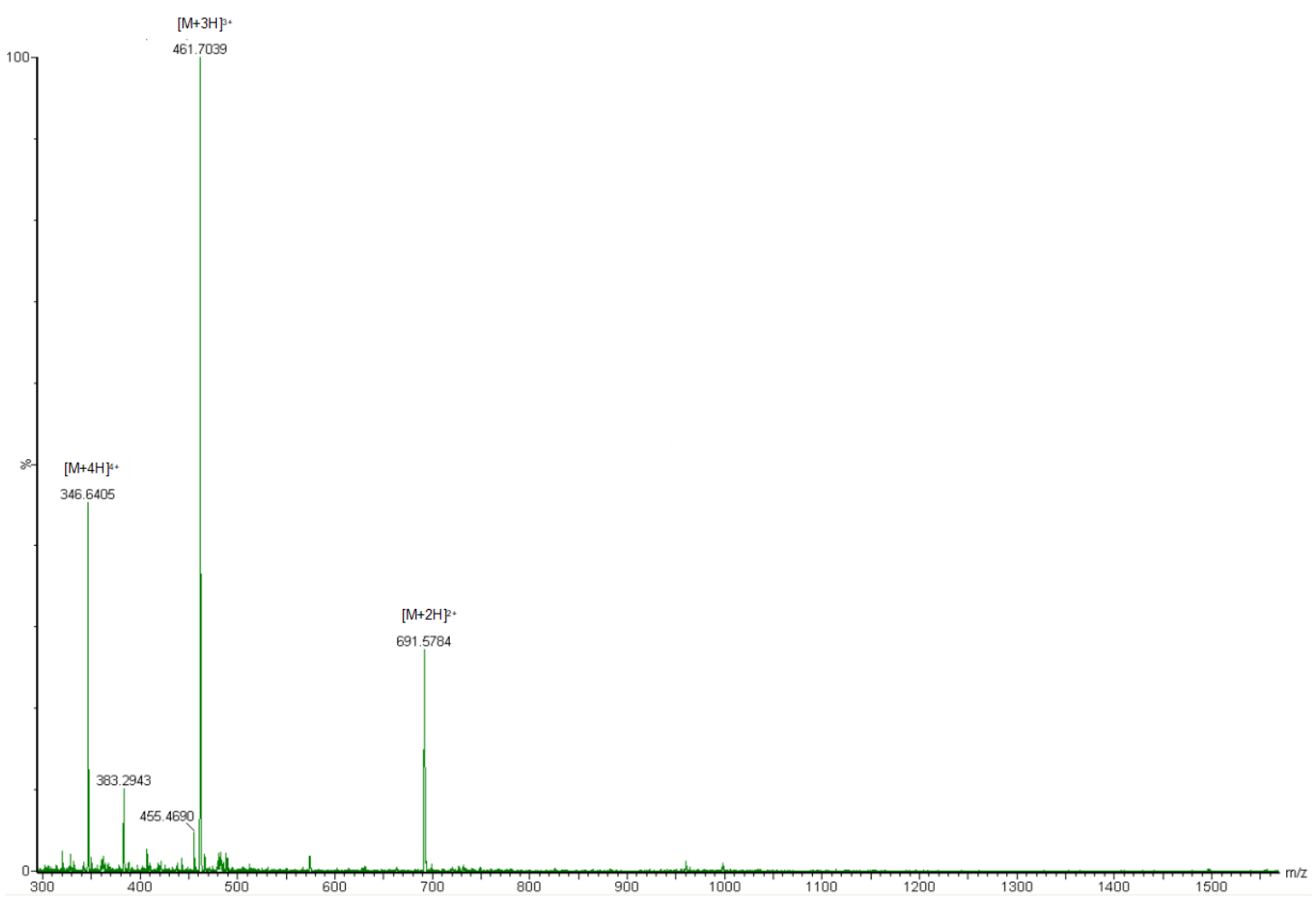

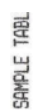

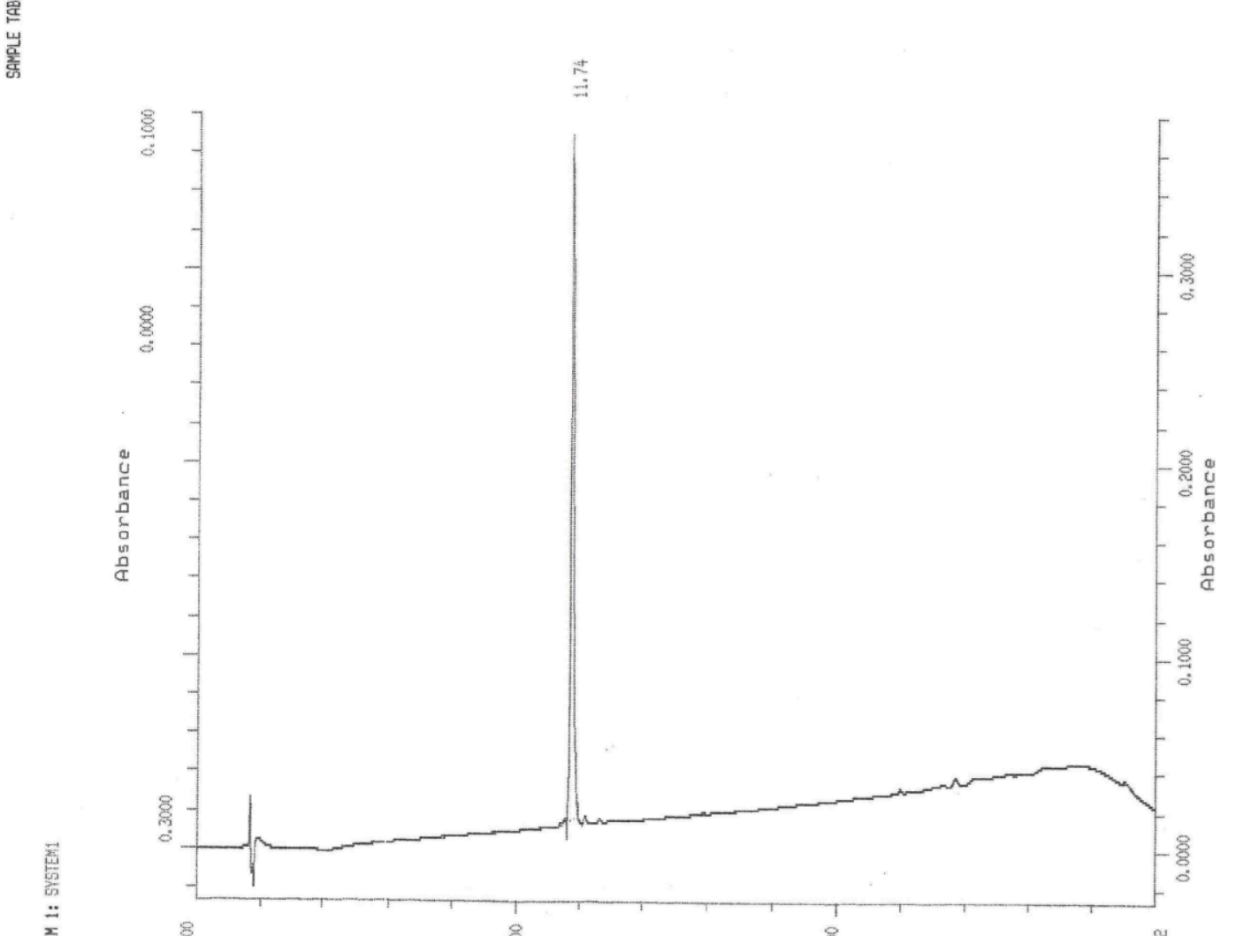


$\left[\mathrm{Tyr}^{1}, \mathrm{Lys}^{5}\right] \mathrm{N} / \mathrm{OFQ}(1-13) \mathrm{NH}_{2}$
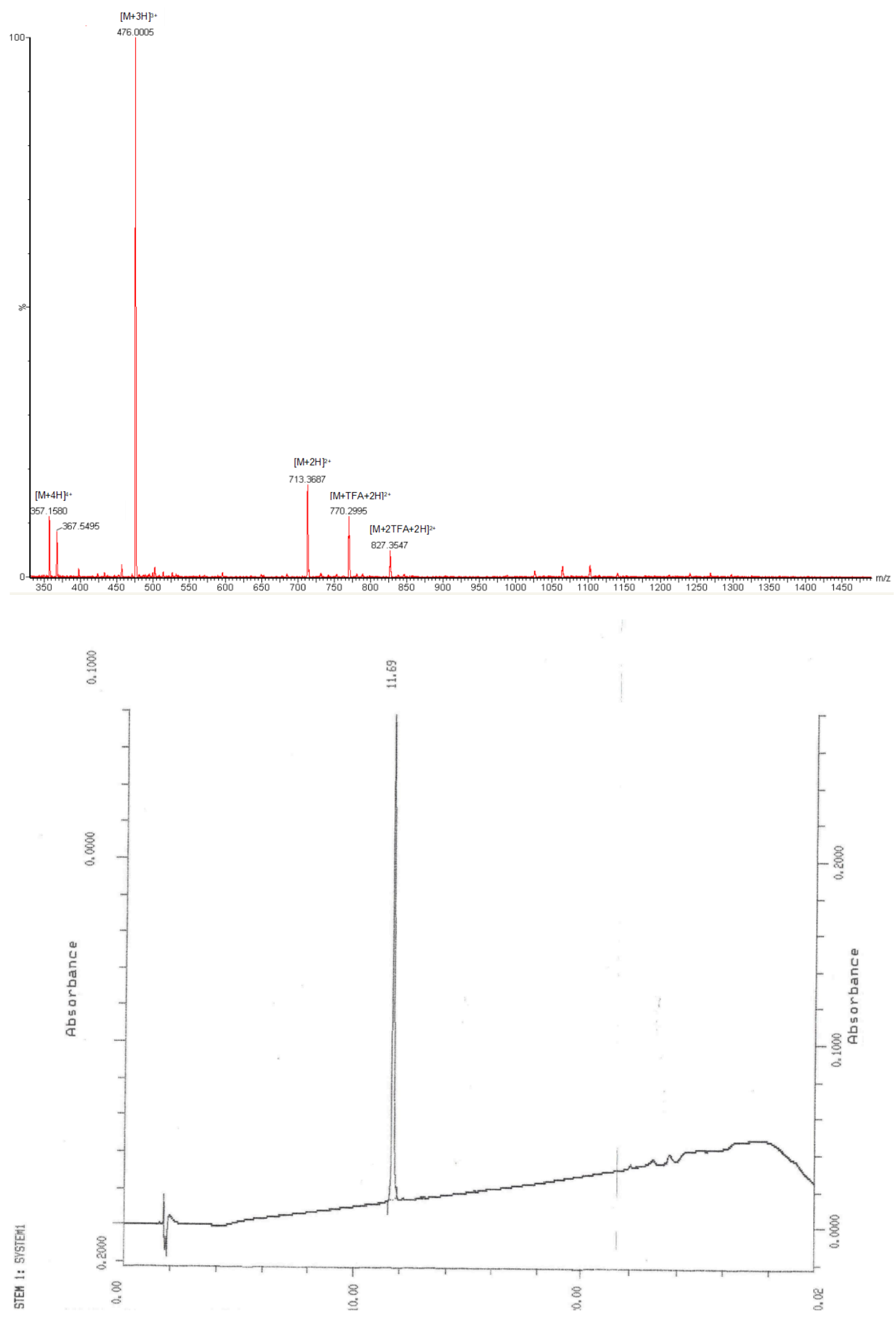
$\left[\mathrm{Tyr}^{1}, \mathrm{Dap}^{5}\right] \mathrm{N} / \mathrm{OFQ}(1-13) \mathrm{NH}_{2}$
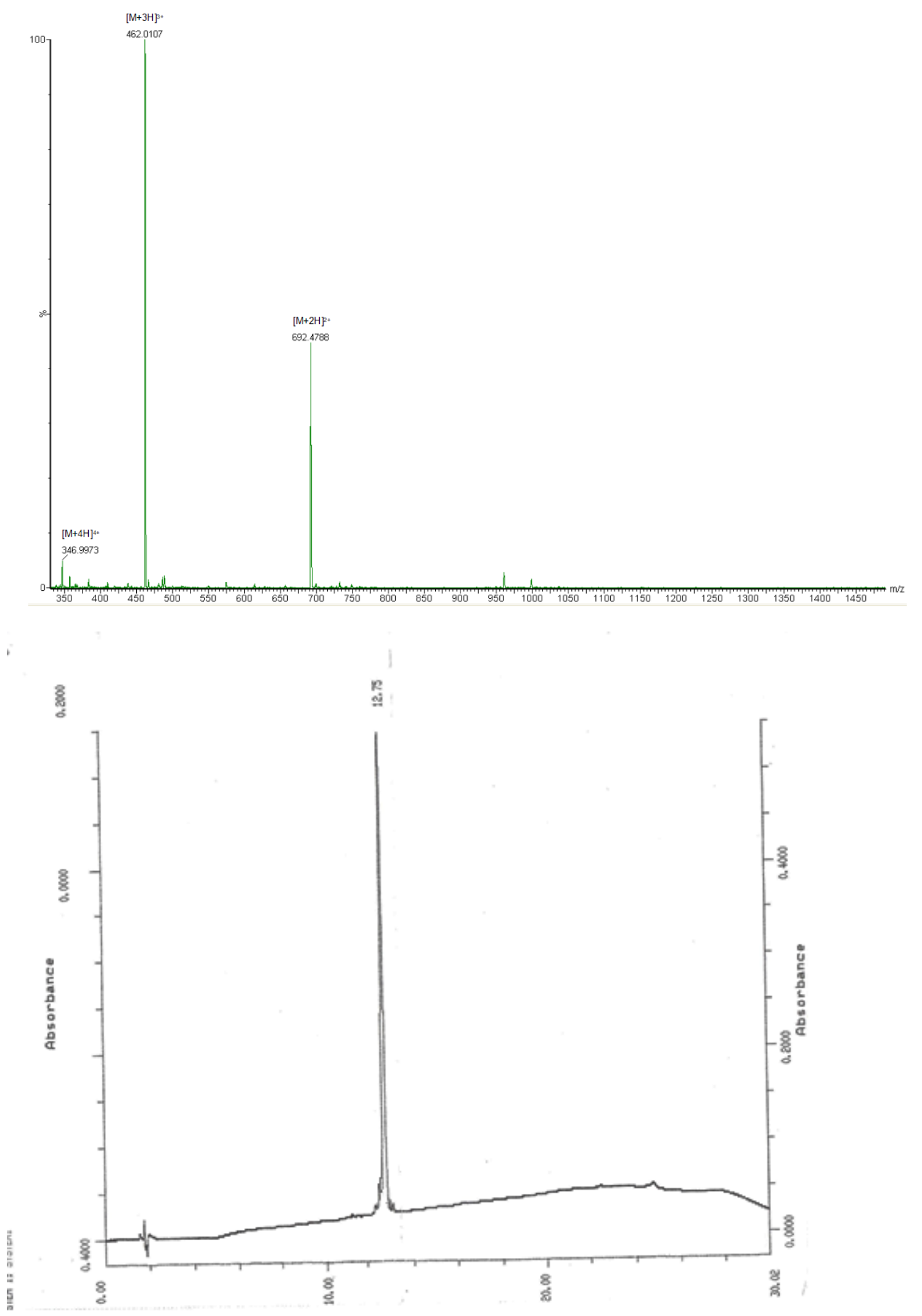
$\left[\mathrm{Tyr}^{1}, \mathrm{Dab}^{5}\right] \mathrm{N} / \mathrm{OFQ}(1-13) \mathrm{NH}_{2}$
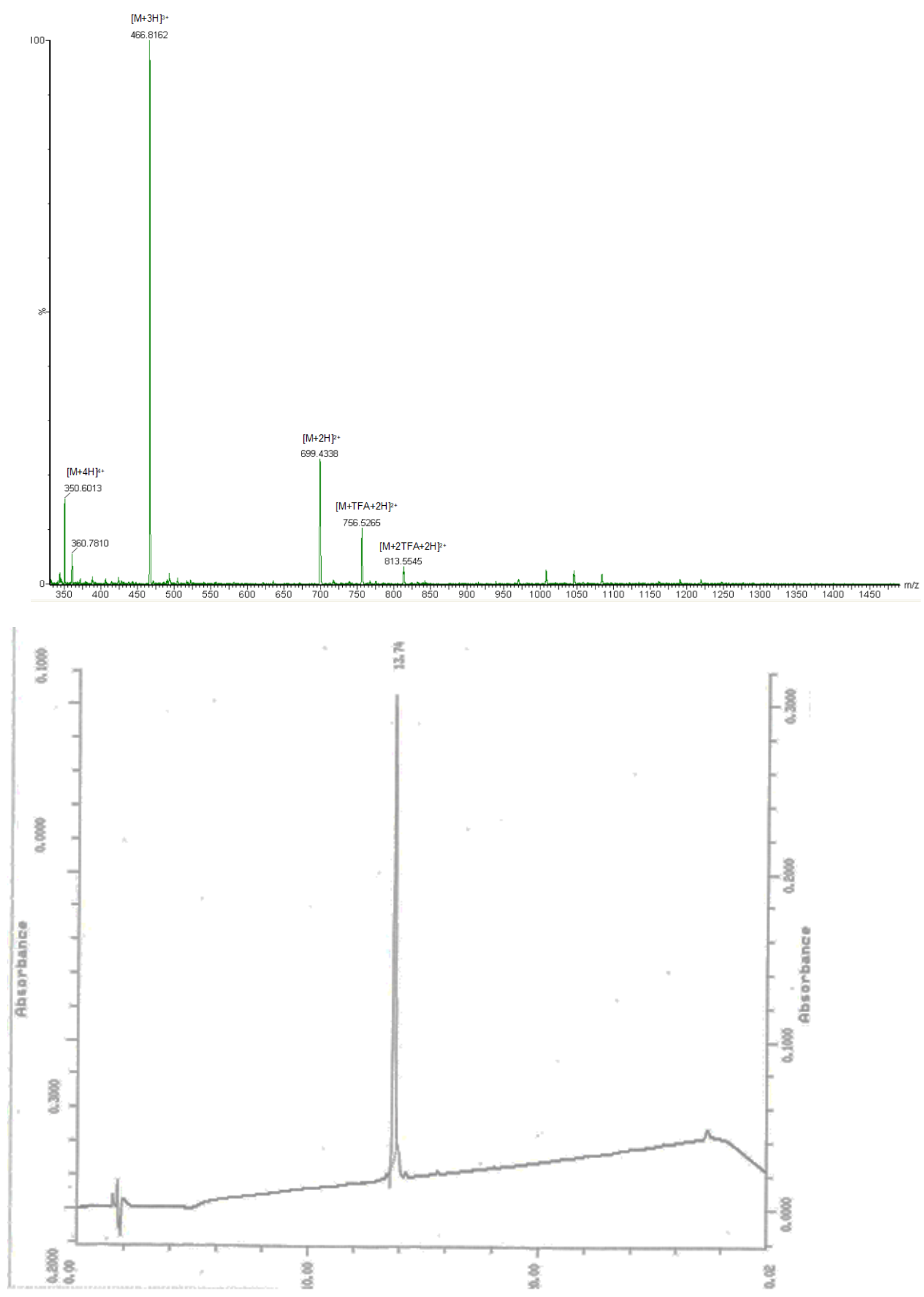
$\left[\mathrm{Tyr}^{1}{ }^{1}\right.$ Leu $\left.^{5}\right] \mathrm{N} / \mathrm{OFQ}(1-13) \mathrm{NH}_{2}$
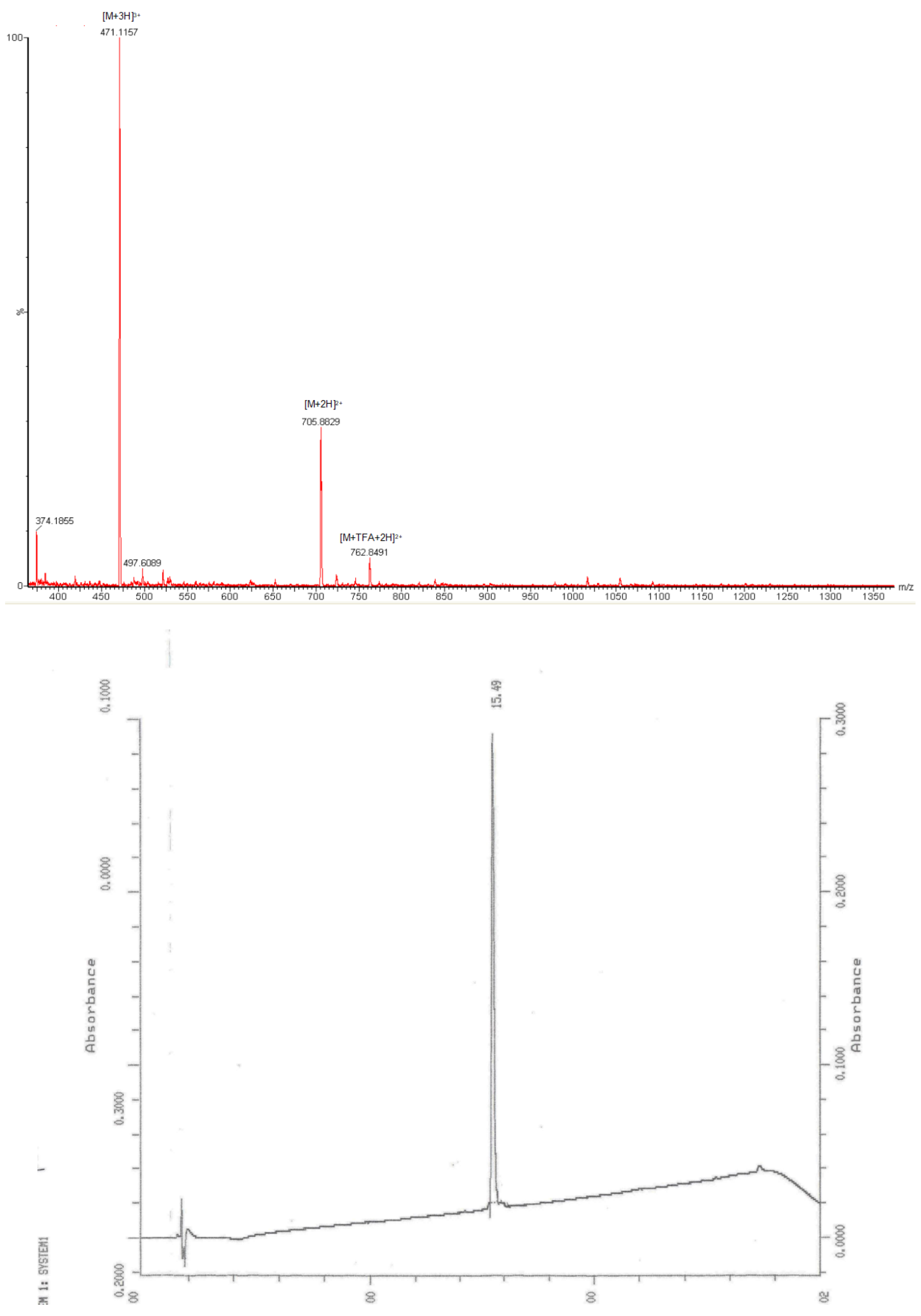
$\left[\mathrm{Tyr}^{1}{ }^{1} \mathrm{Nle}^{5}\right] \mathrm{N} / \mathrm{OFQ}(\mathbf{1 - 1 3}) \mathrm{NH}_{2}$

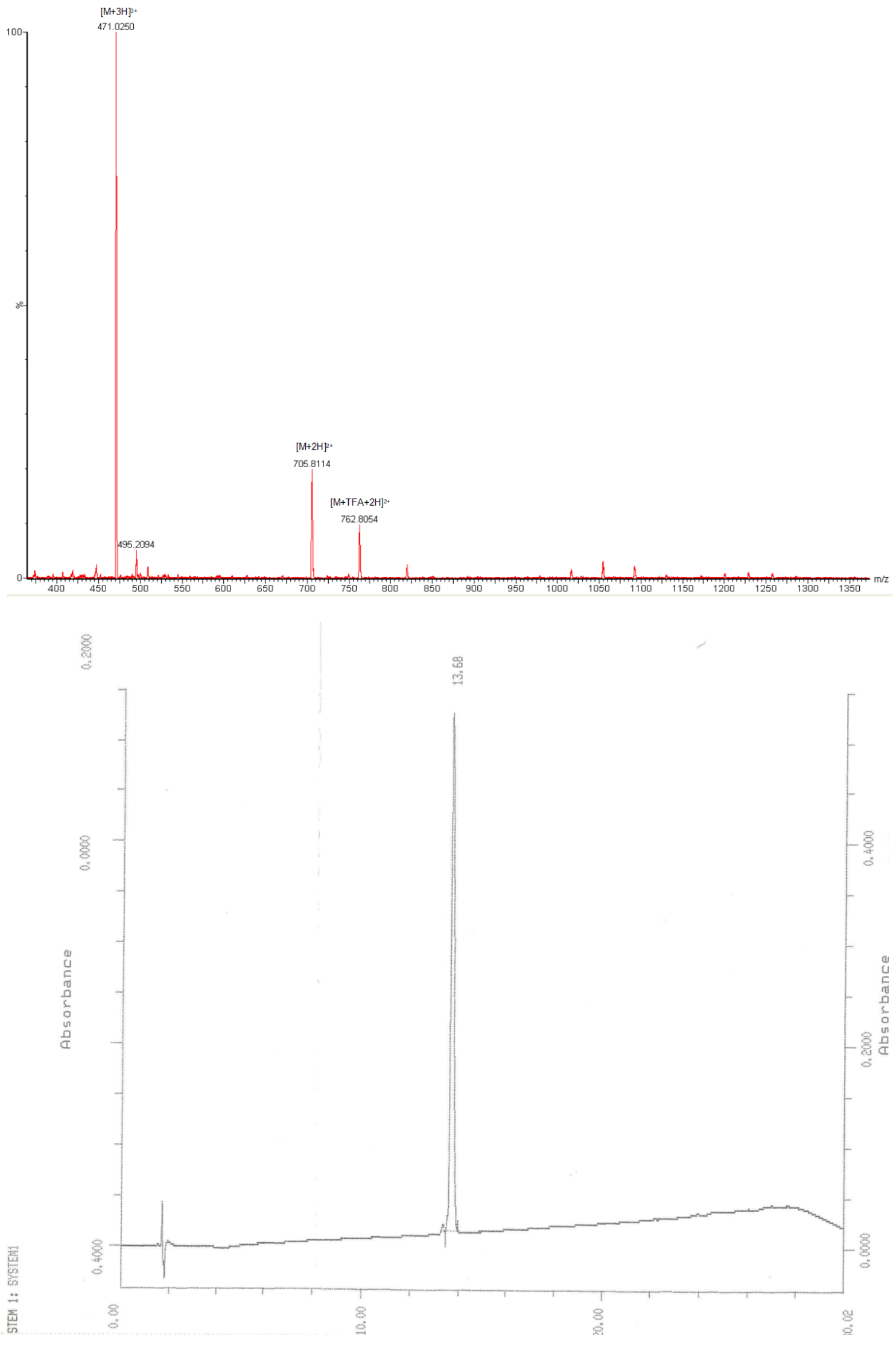

S20 
$\left[\mathrm{Tyr}^{1}{ }^{1} \mathrm{Nva}^{5}\right] \mathrm{N} / \mathrm{OFQ}(1-13) \mathrm{NH}_{2}$

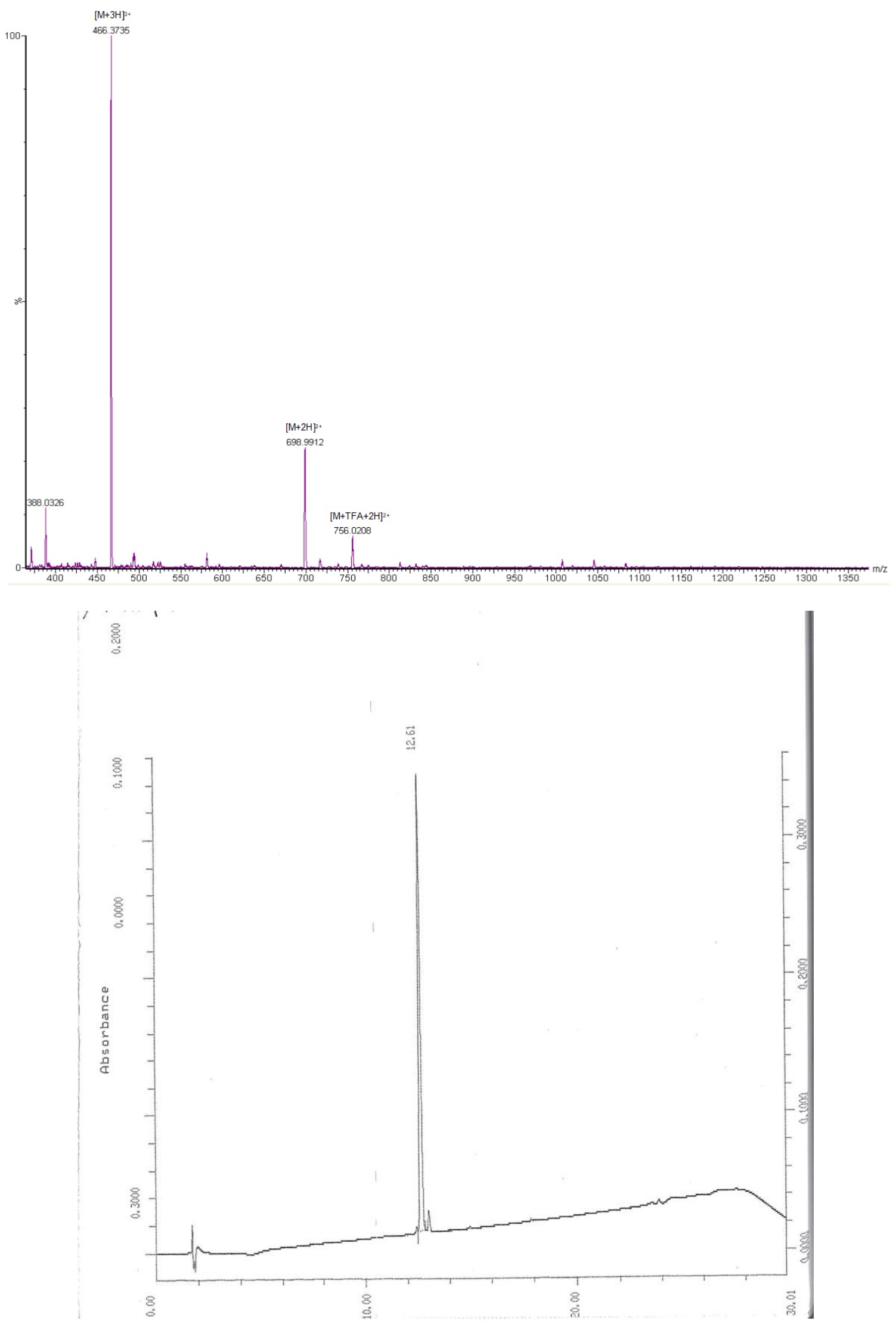

S21 


\section{$\left[\mathrm{Tyr}^{1}, \mathrm{Tyr}^{5}\right] \mathrm{N} / \mathrm{OFQ}(1-13) \mathrm{NH}_{2}$}
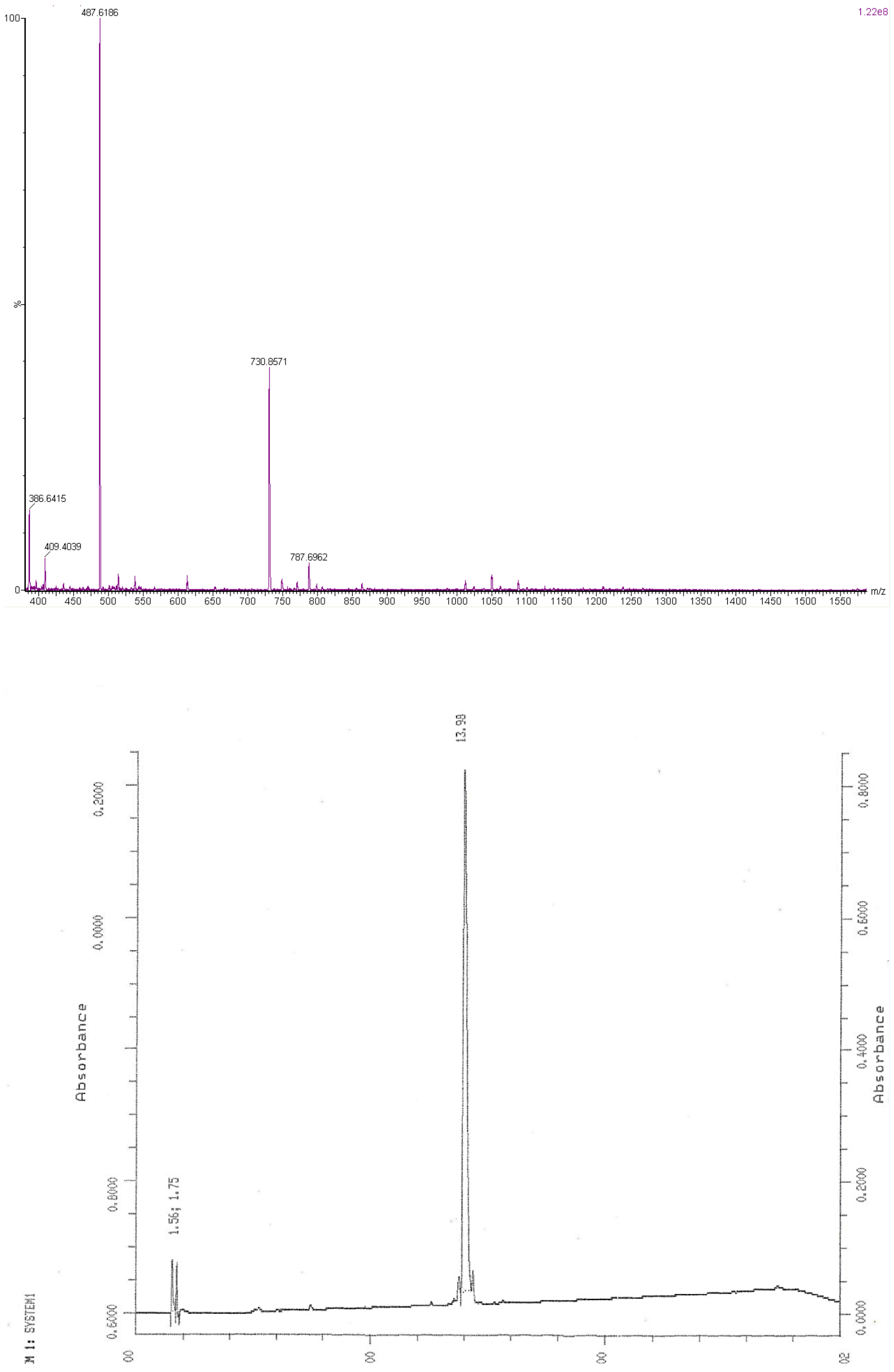
$\left[\mathrm{Tyr}^{1}, \mathrm{Phe}^{5}\right] \mathrm{N} / \mathrm{OFQ}(1-13) \mathrm{NH}_{2}$
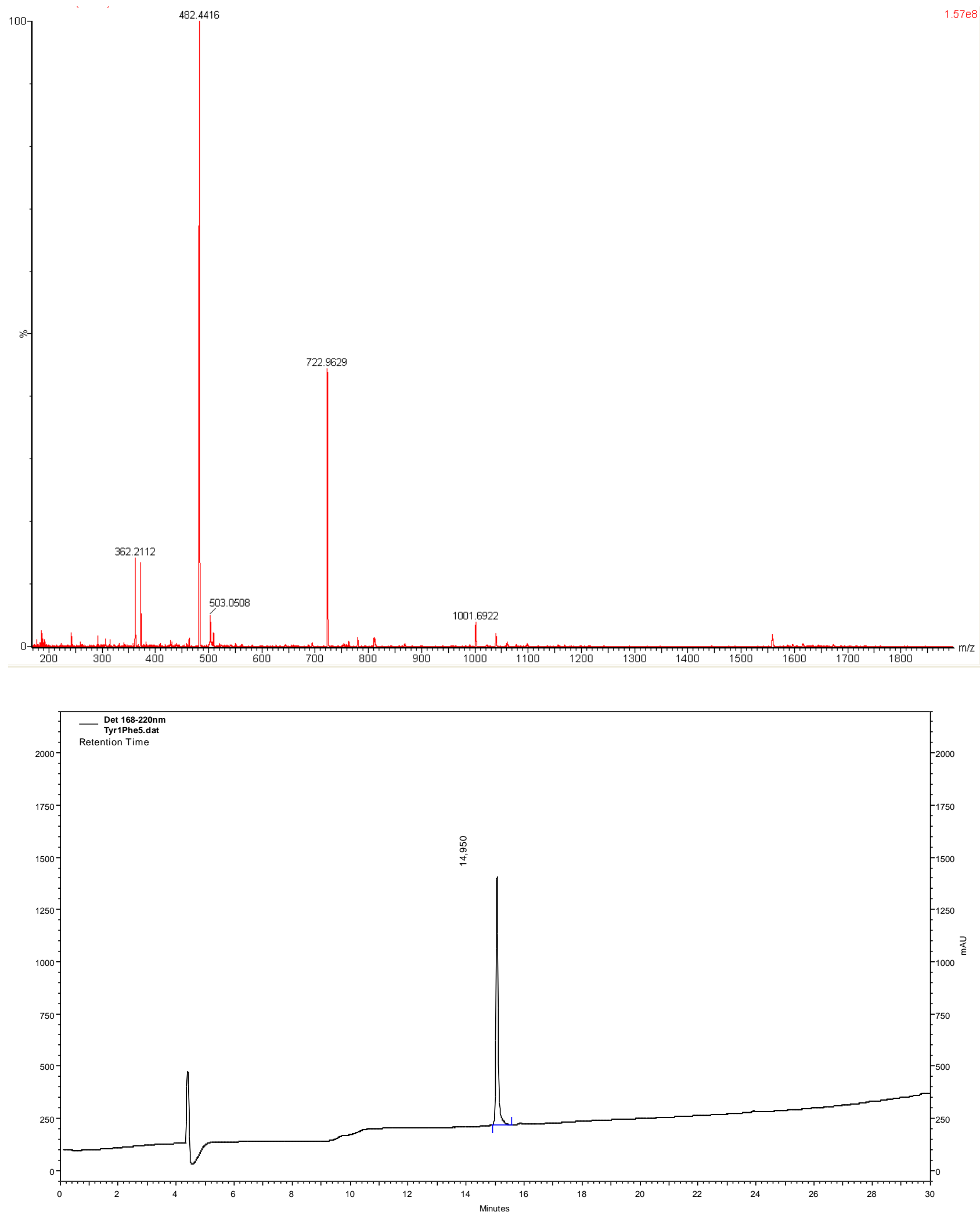

S23 


\section{$\left[\mathrm{Tyr}^{1}, \mathrm{His}^{5}\right] \mathrm{N} / \mathrm{OFQ}(1-13) \mathrm{NH}_{2}$}
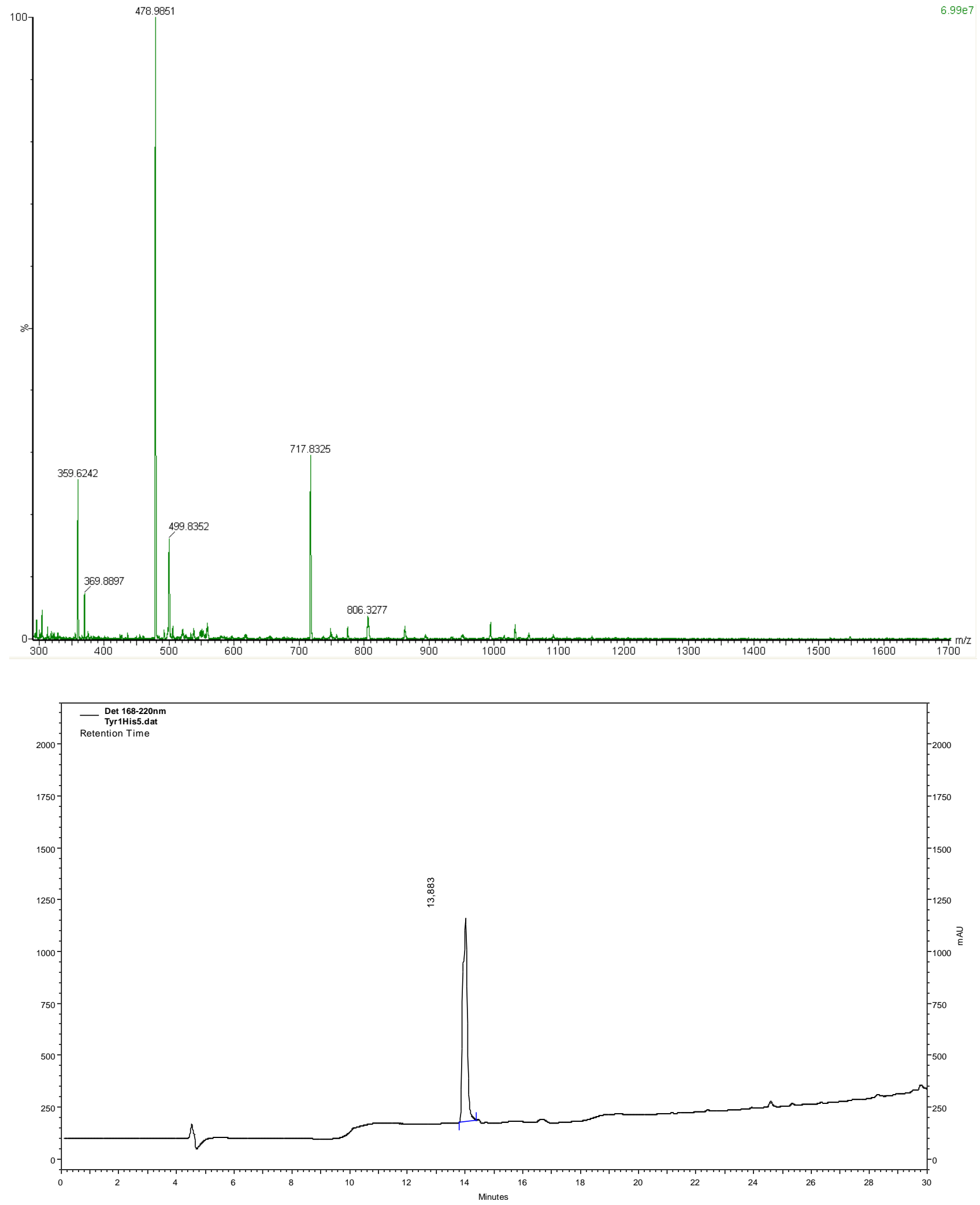
$\left[\mathrm{Tyr}^{1}, \operatorname{Trp}^{5}\right] \mathrm{N} / \mathrm{OFQ}(1-13) \mathrm{NH}_{2}$
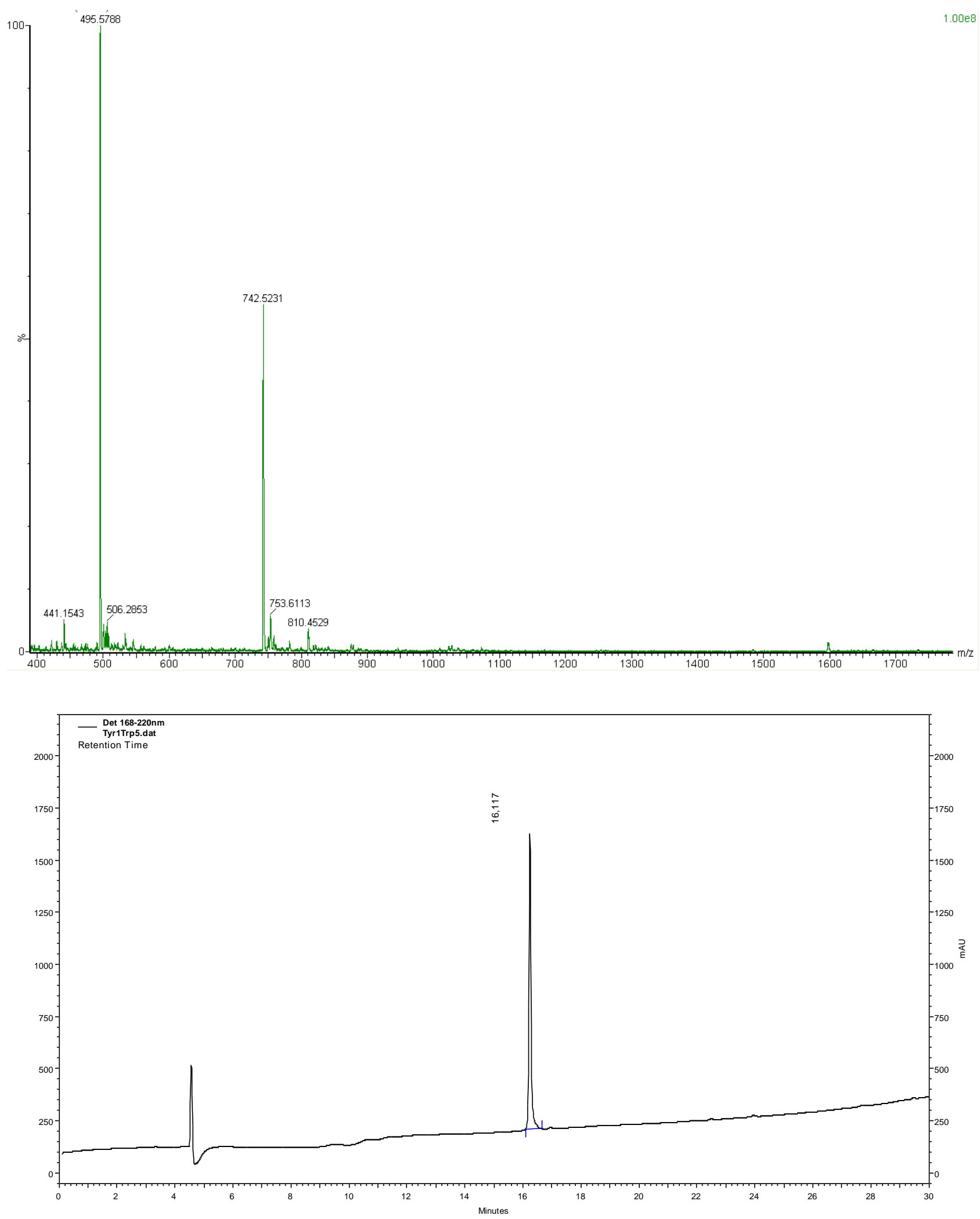

S25 


\section{$\left[\mathrm{Tyr}^{1}, \mathrm{hPhe}^{5}\right] \mathrm{N} / \mathrm{OFQ}(1-13) \mathrm{NH}_{2}$}
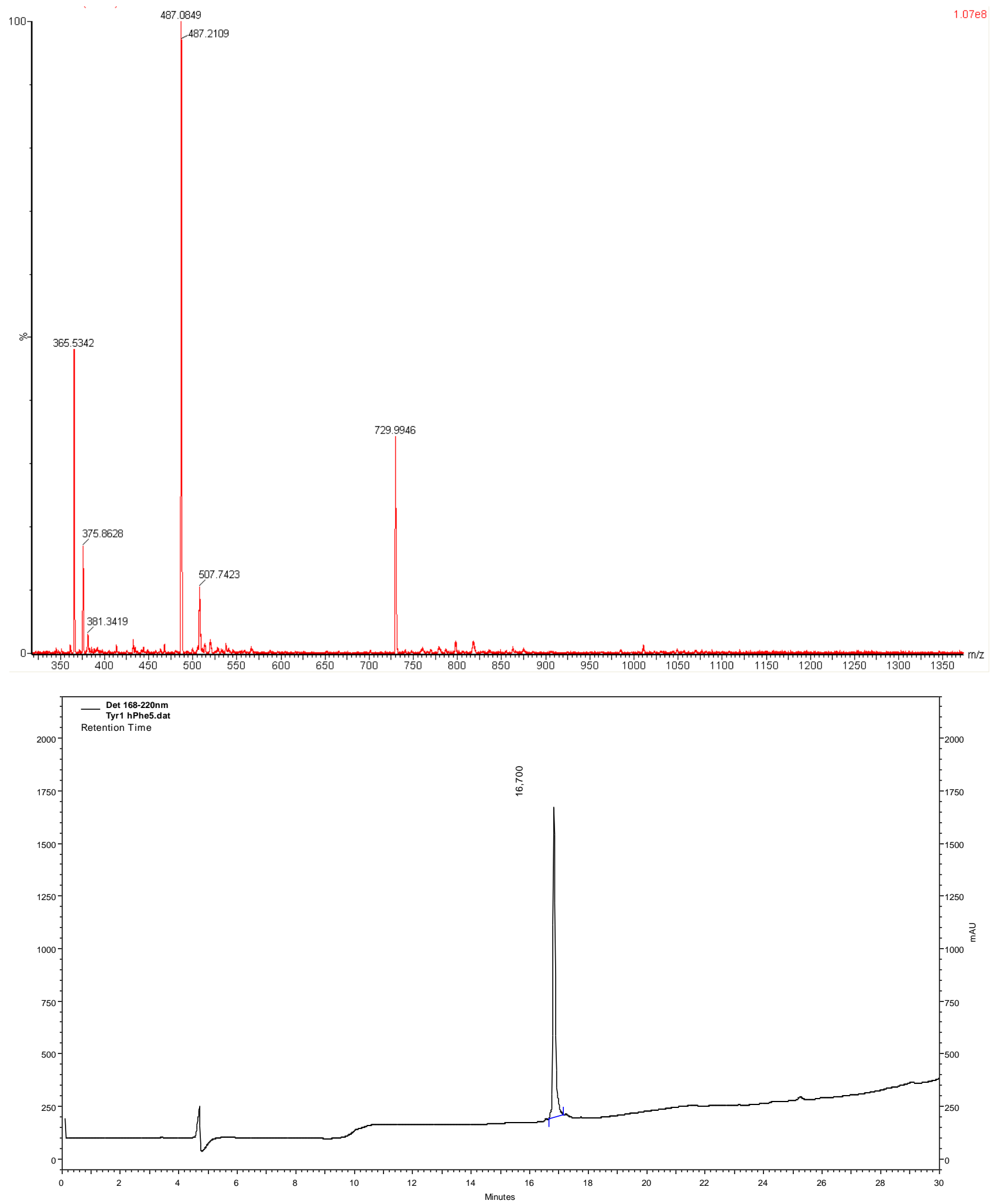
$\left[\right.$ Tyr $^{1}{ }^{1}$ Phg $\left.^{5}\right]$ N/OFQ(1-13) NH $_{2}$
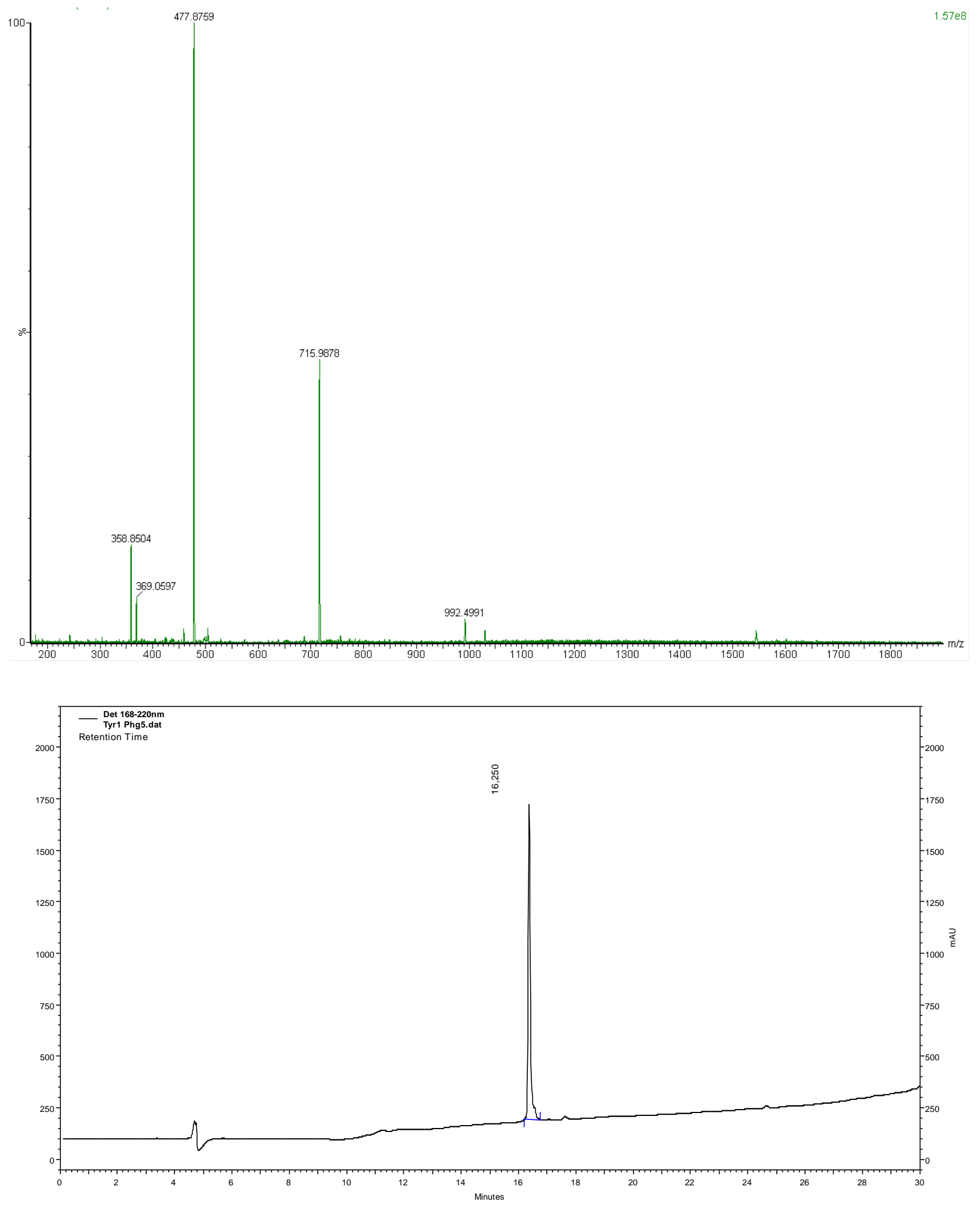

S27 
$\left[\mathrm{Tyr}^{1}, \mathbf{p}\left(\mathrm{OCH}_{3}\right) \mathrm{Phe}^{5}\right] \mathrm{N} / \mathrm{OFQ}(1-13) \mathrm{NH}_{2}$

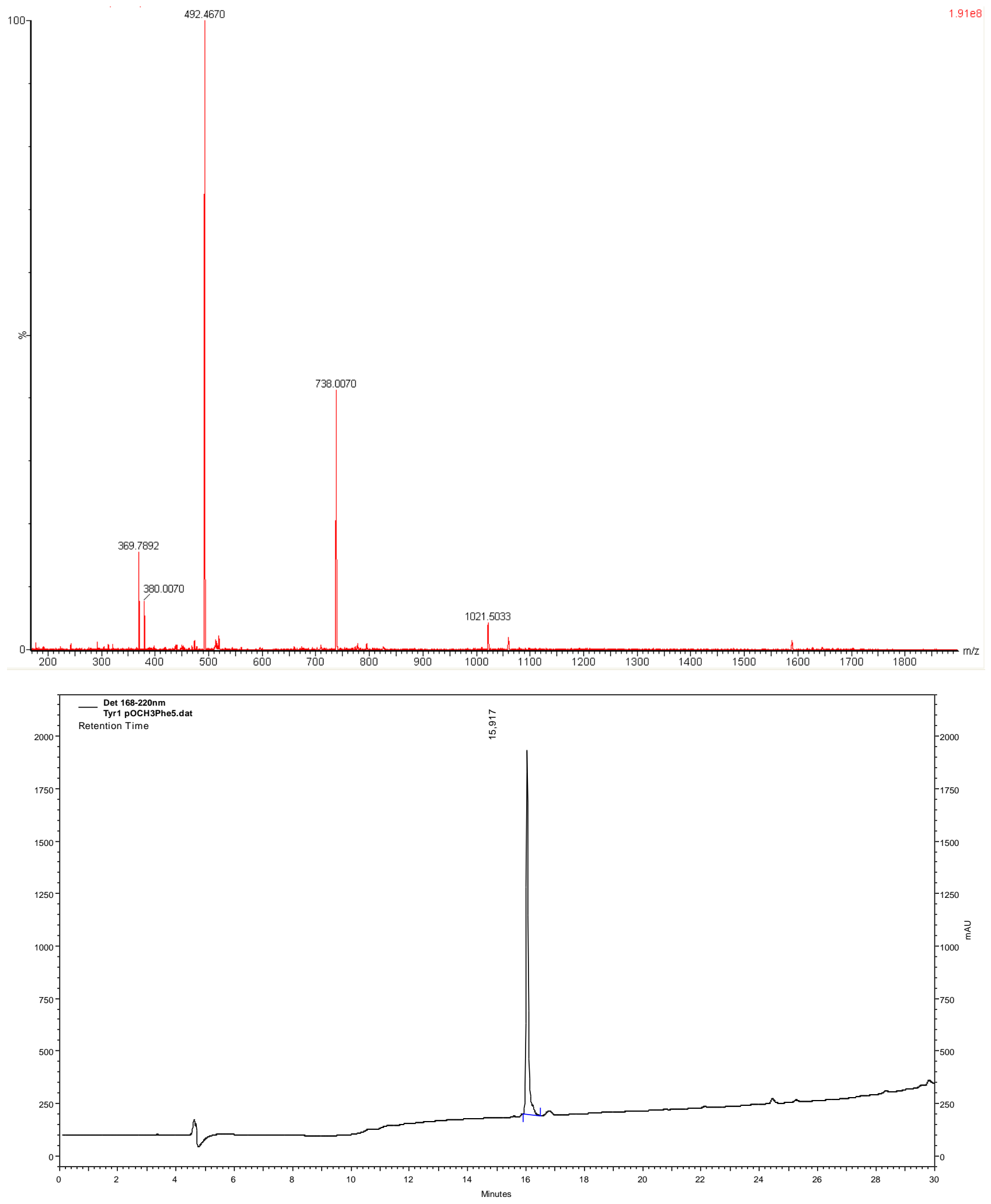

$\mathrm{S} 28$ 
$\left[\mathrm{Tyr}^{1}, \mathrm{pFPhe}^{5}\right] \mathrm{N} / \mathrm{OFQ}(1-13) \mathrm{NH}_{2}$

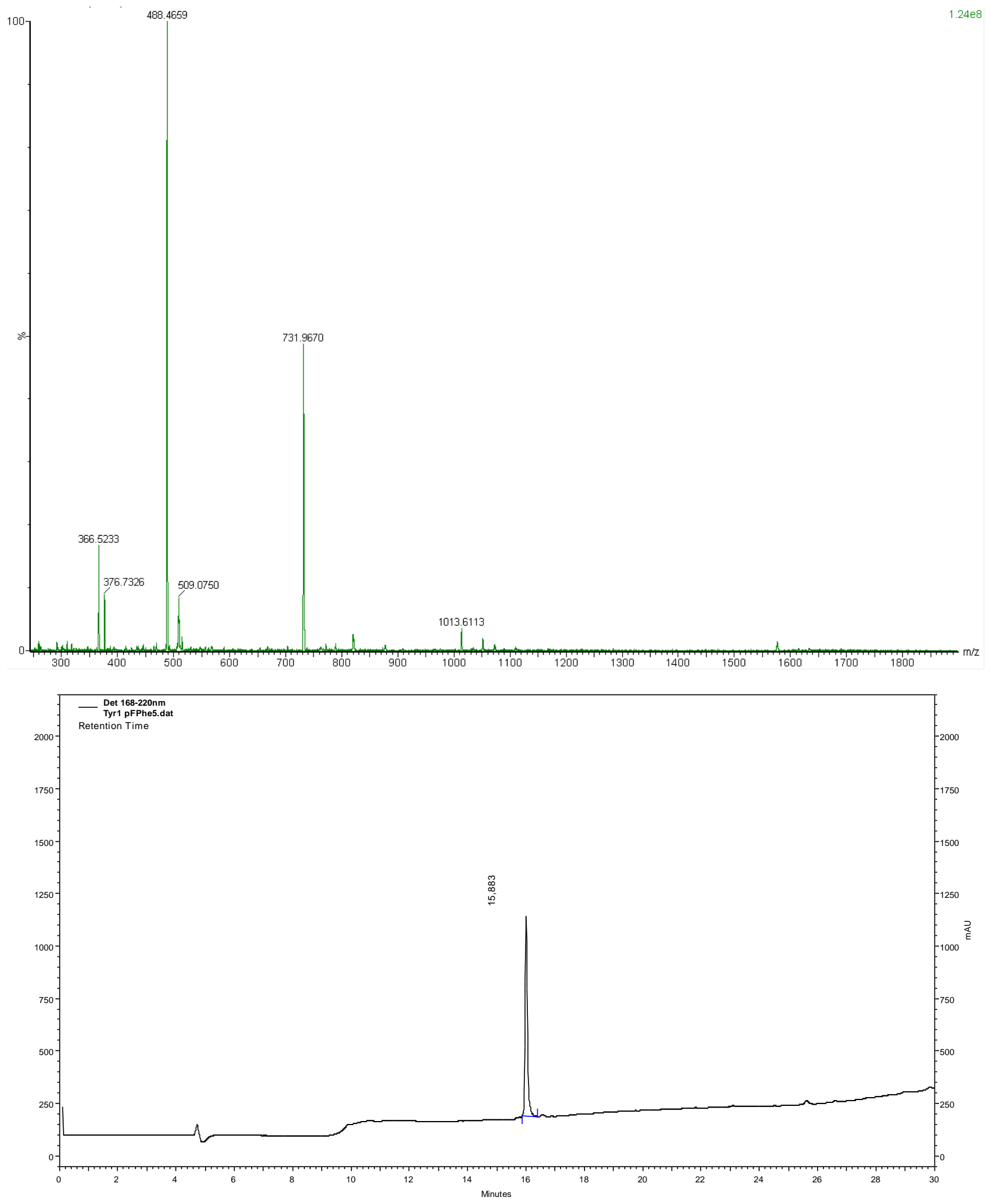

S29 
$\left[\mathrm{Tyr}^{1}, \mathrm{p}\left(\mathrm{NO}_{2}\right) \mathrm{Phe}^{5}\right] \mathrm{N} / \mathrm{OFQ}(1-13) \mathrm{NH}_{2}$
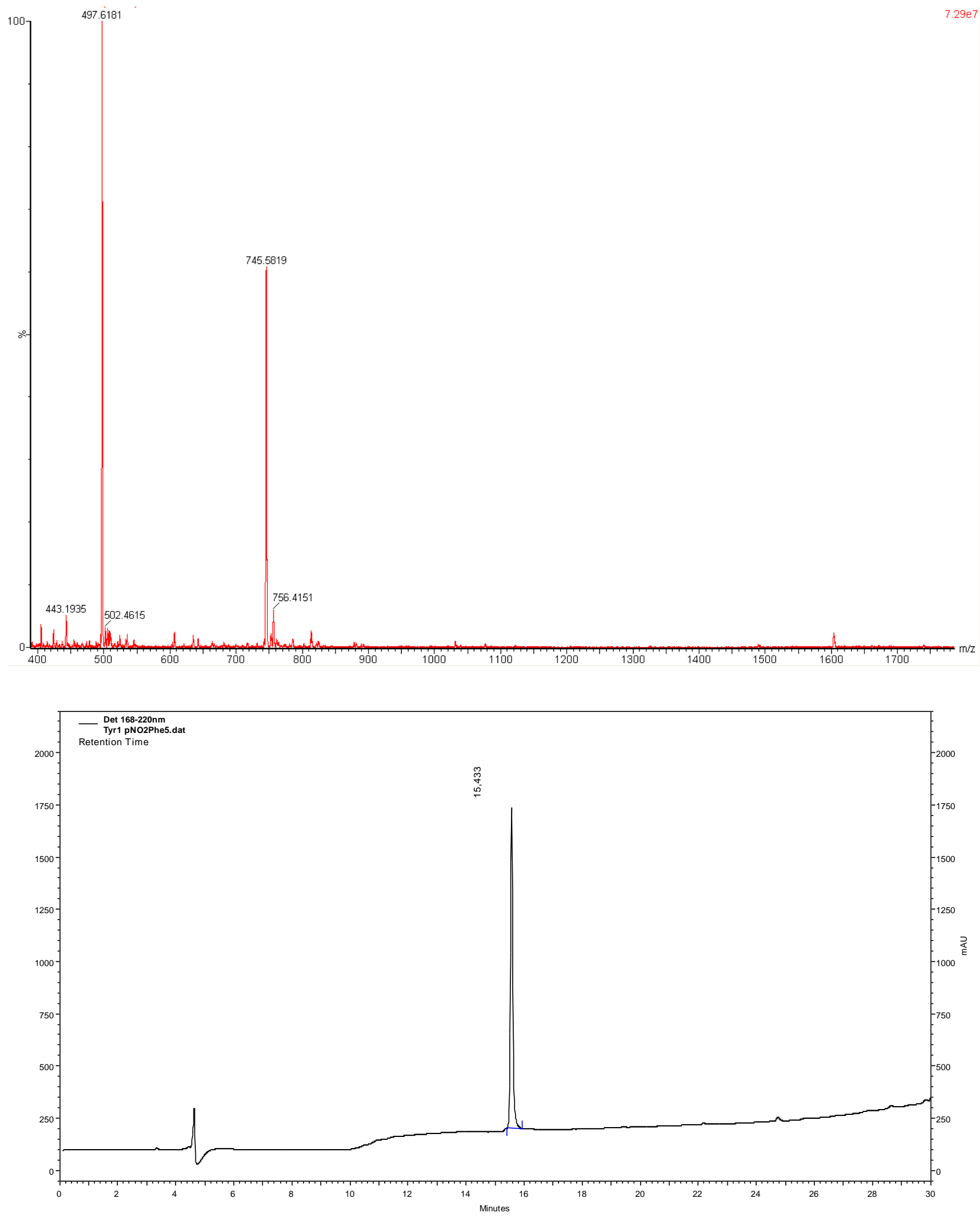

S30 
$\left[\mathrm{Tyr}^{1}{ }^{1}\right.$ Dip $\left.^{5}\right] \mathrm{N} / \mathrm{OFQ}(1-13) \mathrm{NH}_{2}$

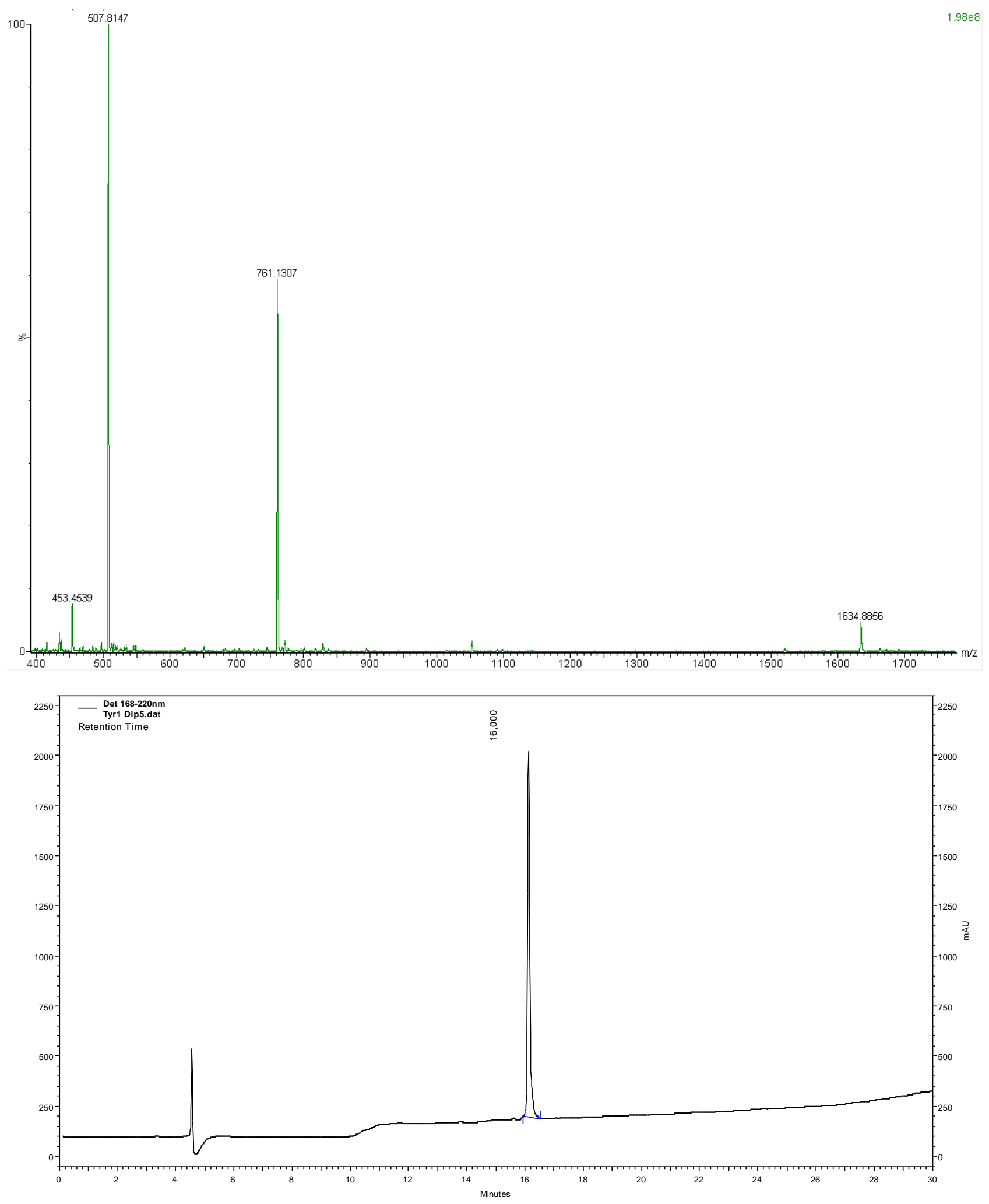

S31 


\section{$\left[\mathrm{Tyr}^{1}, \mathrm{Bip}^{5}\right] \mathrm{N} / \mathrm{OFQ}(1-13) \mathrm{NH}_{2}$}
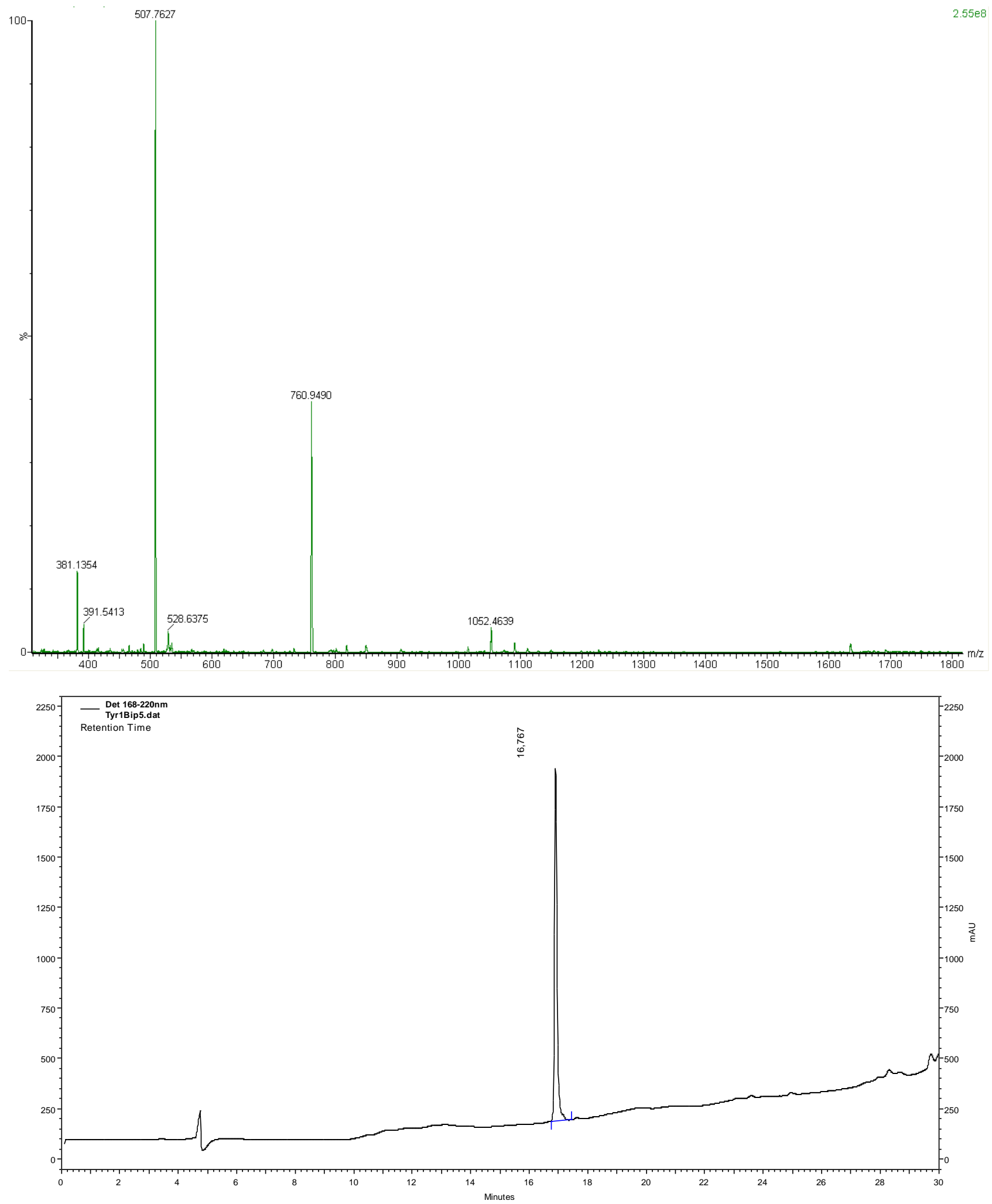


\section{$\left[\mathrm{Tyr}^{1},{ }^{1} \mathrm{Nal}^{5}\right] \mathrm{N} / \mathrm{OFQ}(1-13) \mathrm{NH}_{2}$}
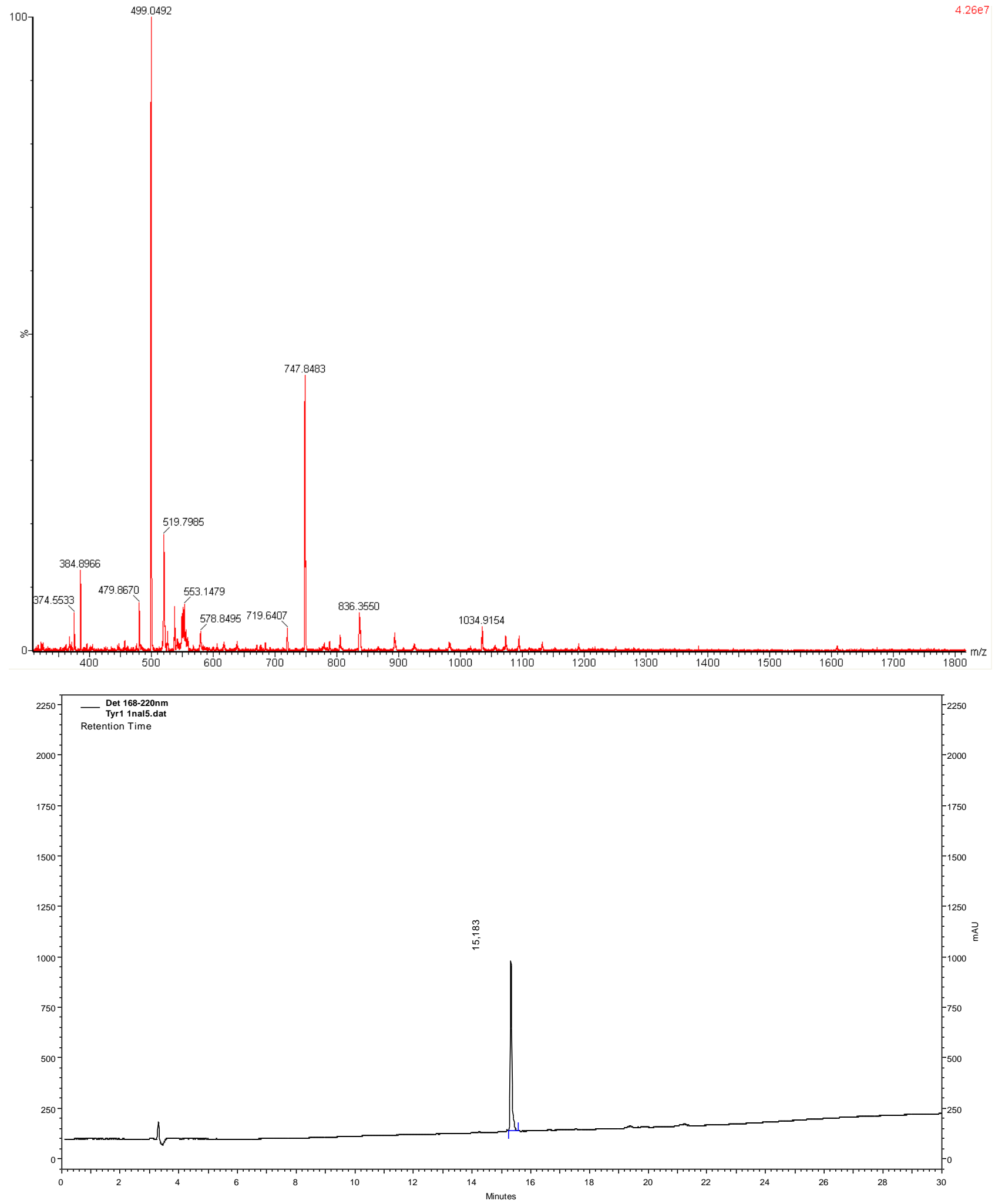


\section{$\left[\mathrm{Tyr}^{1},{ }^{2} \mathrm{Nal}^{5}\right] \mathrm{N} / \mathrm{OFQ}(1-13) \mathrm{NH}_{2}$}
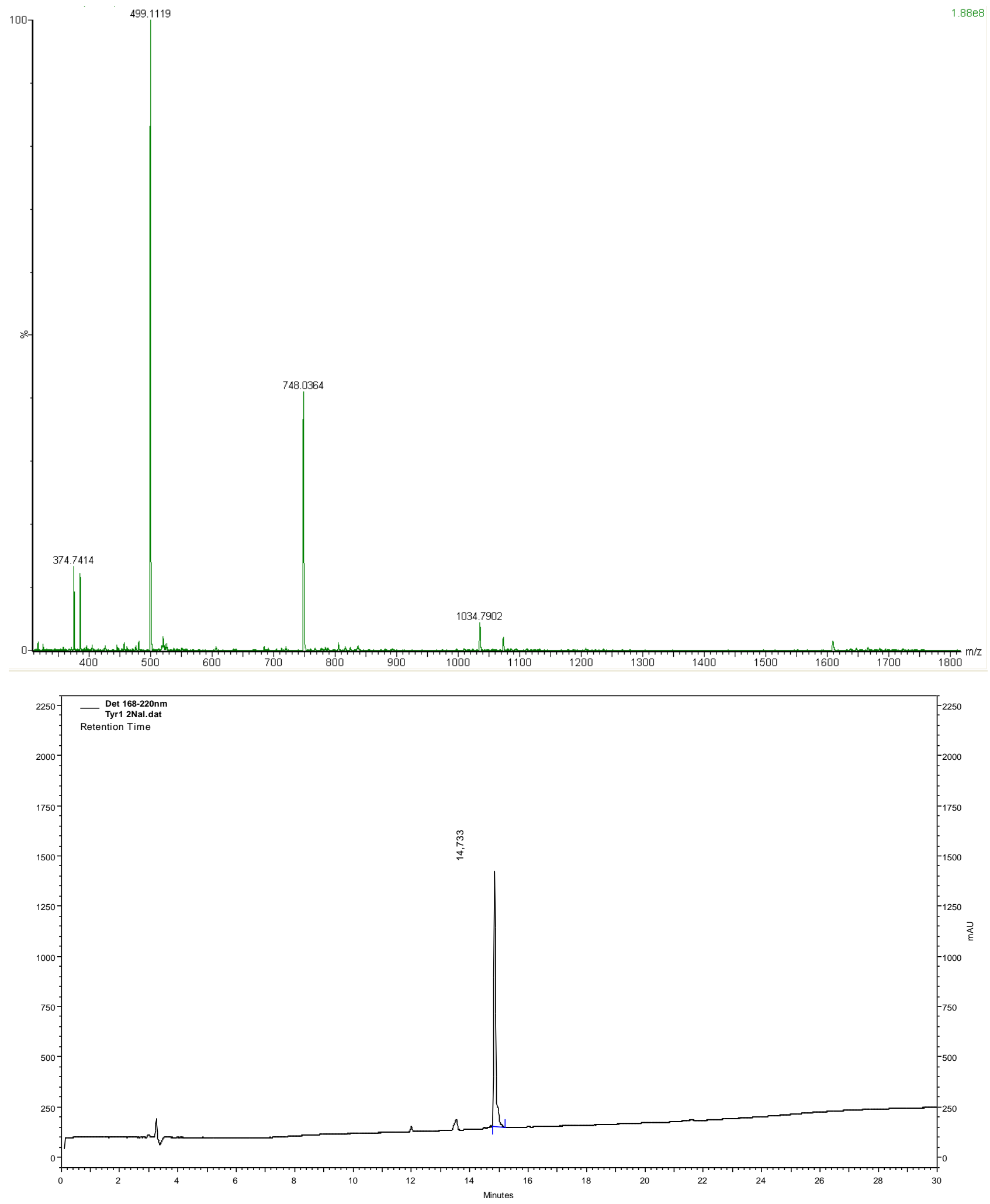
$\left[\mathrm{Tyr}^{1}, \mathrm{p}\left(\mathrm{NH}_{2}\right) \mathrm{Phe}^{5}\right] \mathrm{N} / \mathrm{OFQ}(1-13) \mathrm{NH}_{2}$
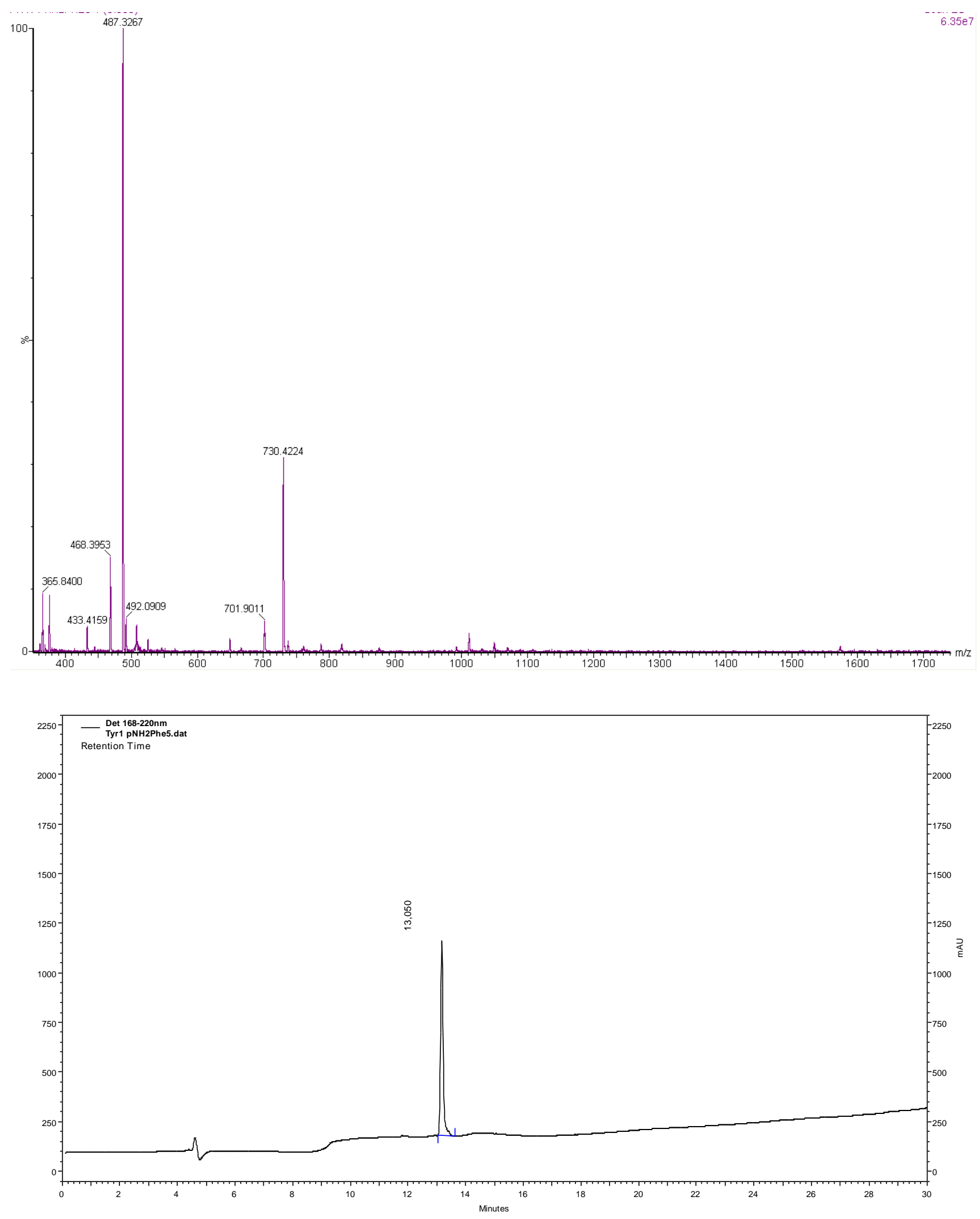


\section{$\left[\mathrm{Tyr}^{1}, \mathrm{Dmt}^{5}\right] \mathrm{N} / \mathrm{OFQ}(1-13) \mathrm{NH}_{2}$}
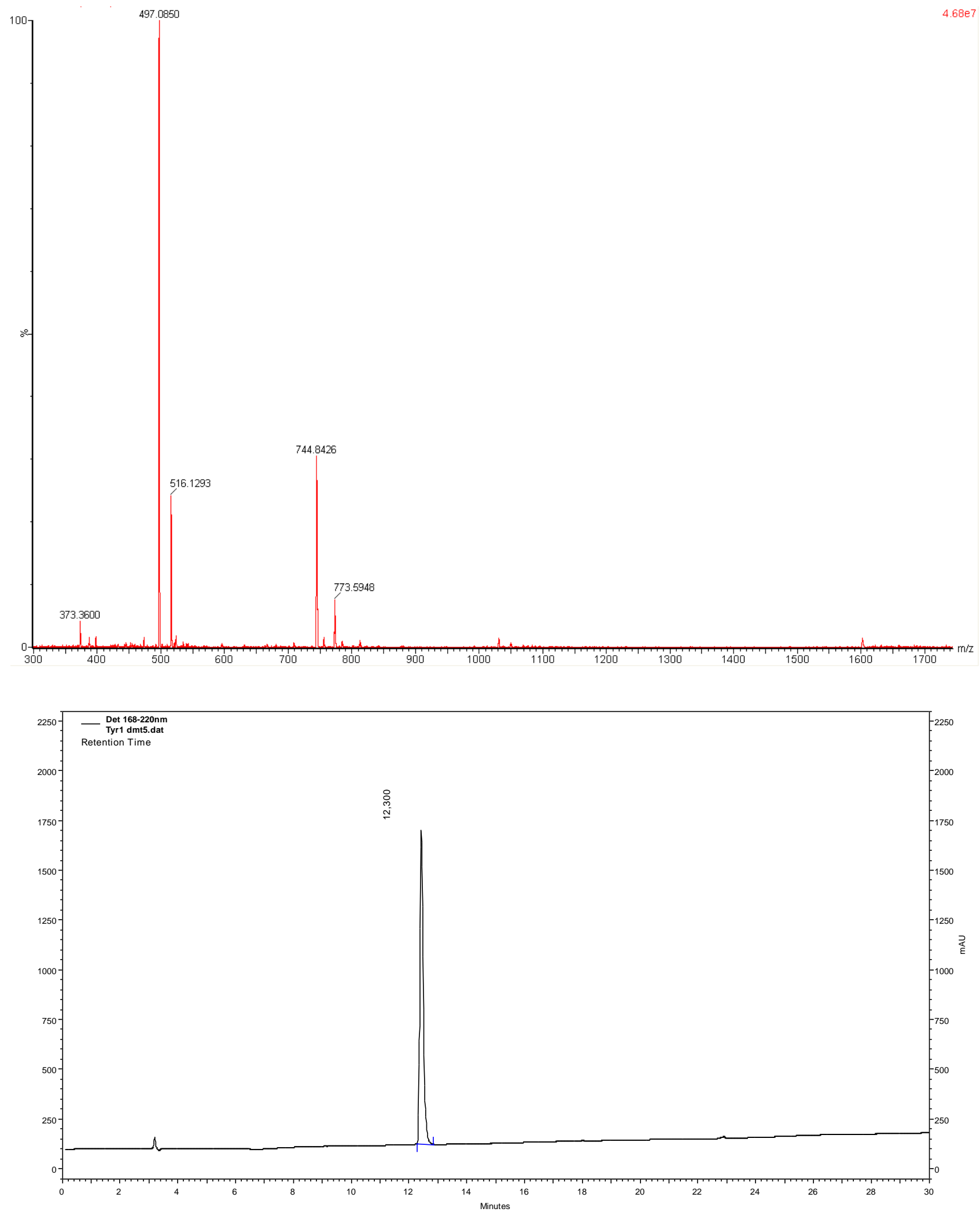


\section{$\left[\mathrm{Dmt}^{1}{ }^{1} \mathrm{Phe}^{5}\right] \mathrm{N} / \mathrm{OFQ}(1-13) \mathrm{NH}_{2}$}
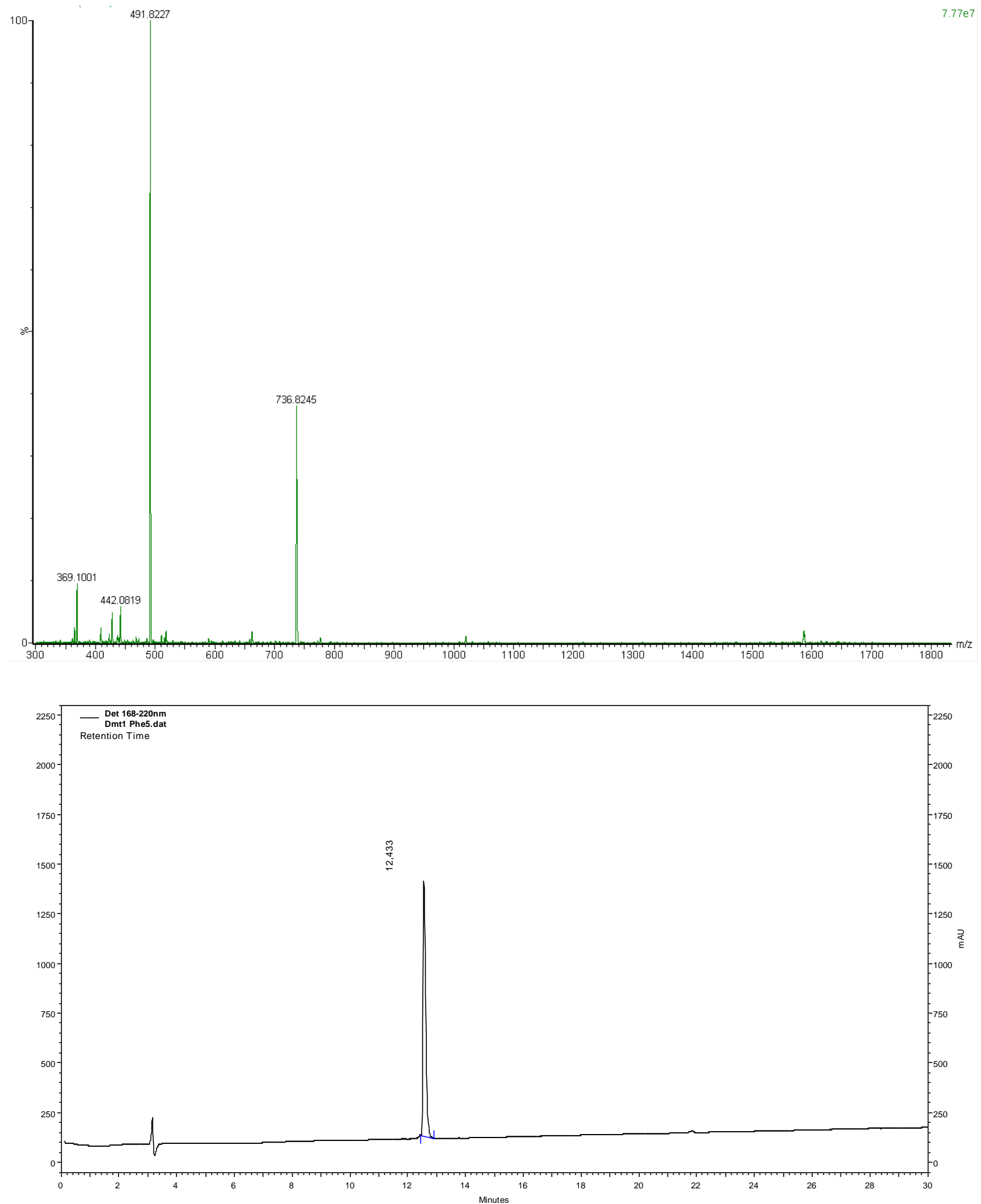
$\left[\right.$ Dmt $^{1}{ }^{1}$ Phg $\left.^{5}\right]$ N/OFQ(1-13) $\mathbf{N H}_{2}$
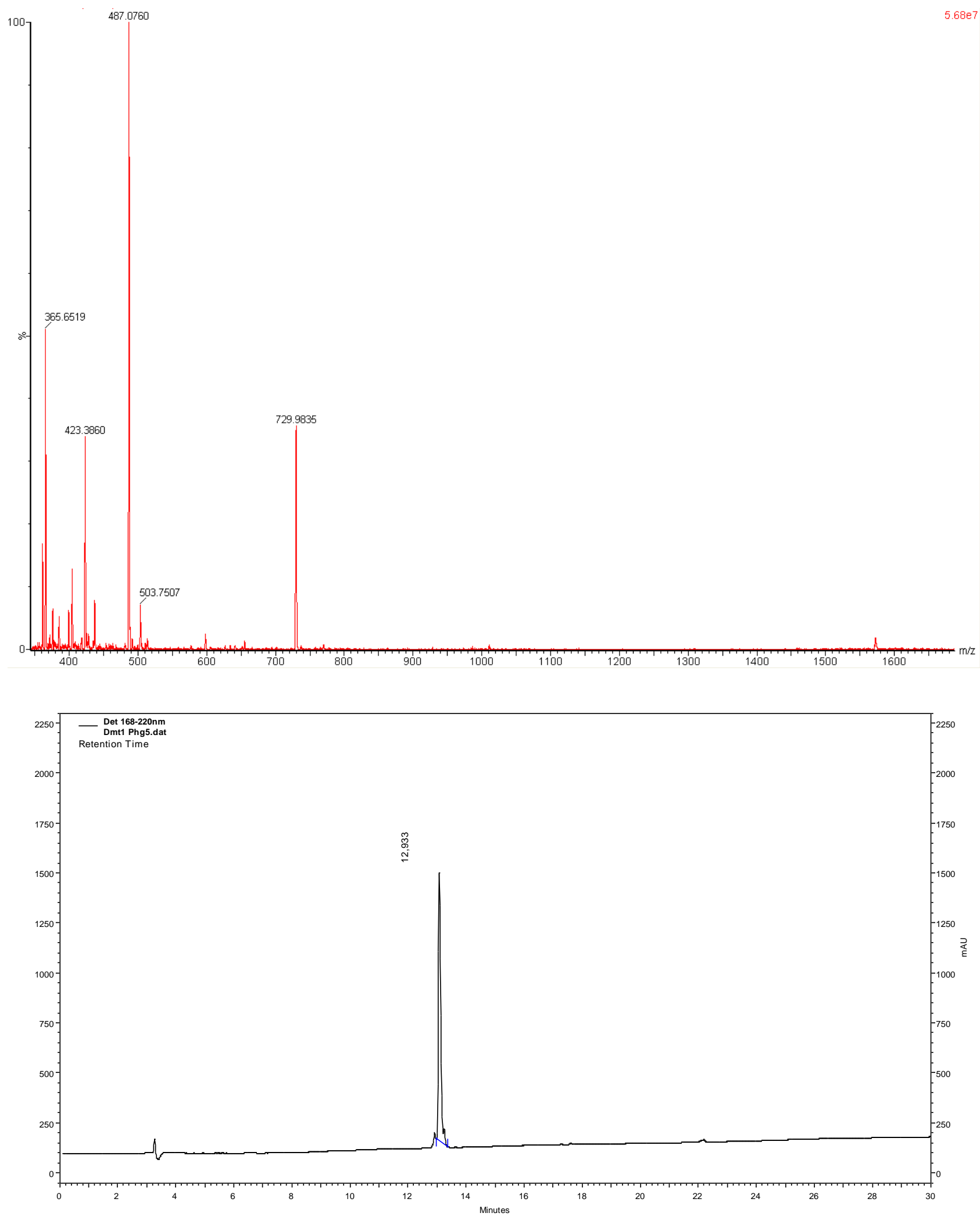

S38 


\section{$\left[\mathrm{Dmt}^{1}, \mathbf{1 N a l}^{5}\right] \mathrm{N} / \mathrm{OFQ}(\mathbf{1 - 1 3}) \mathrm{NH}_{2}$}
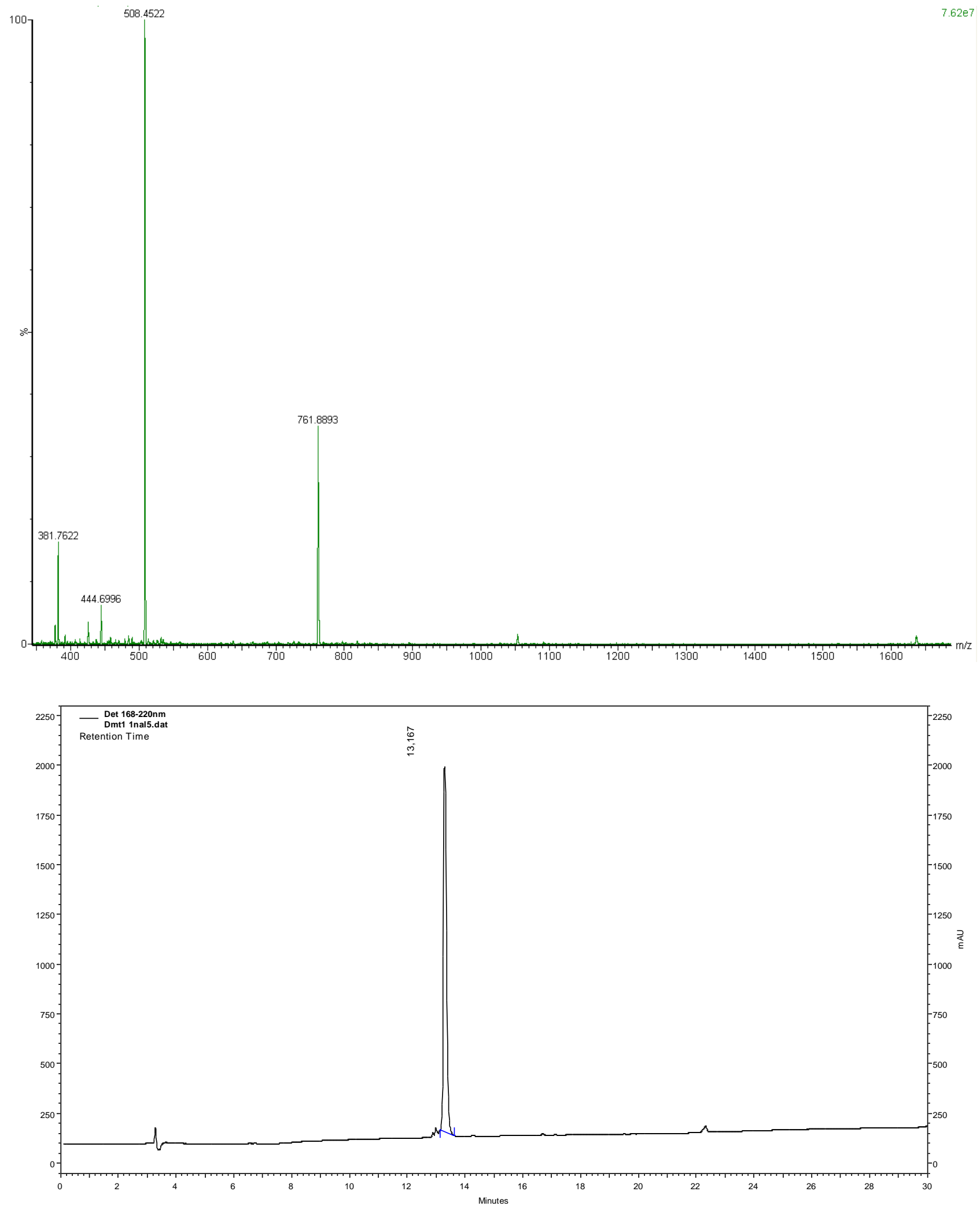


\section{$\left[\mathrm{Dmt}^{1}, \mathbf{p}\left(\mathrm{NH}_{2}\right) \mathrm{Phe}^{5}\right] \mathrm{N} / \mathrm{OFQ}(1-13) \mathrm{NH}_{2}$}
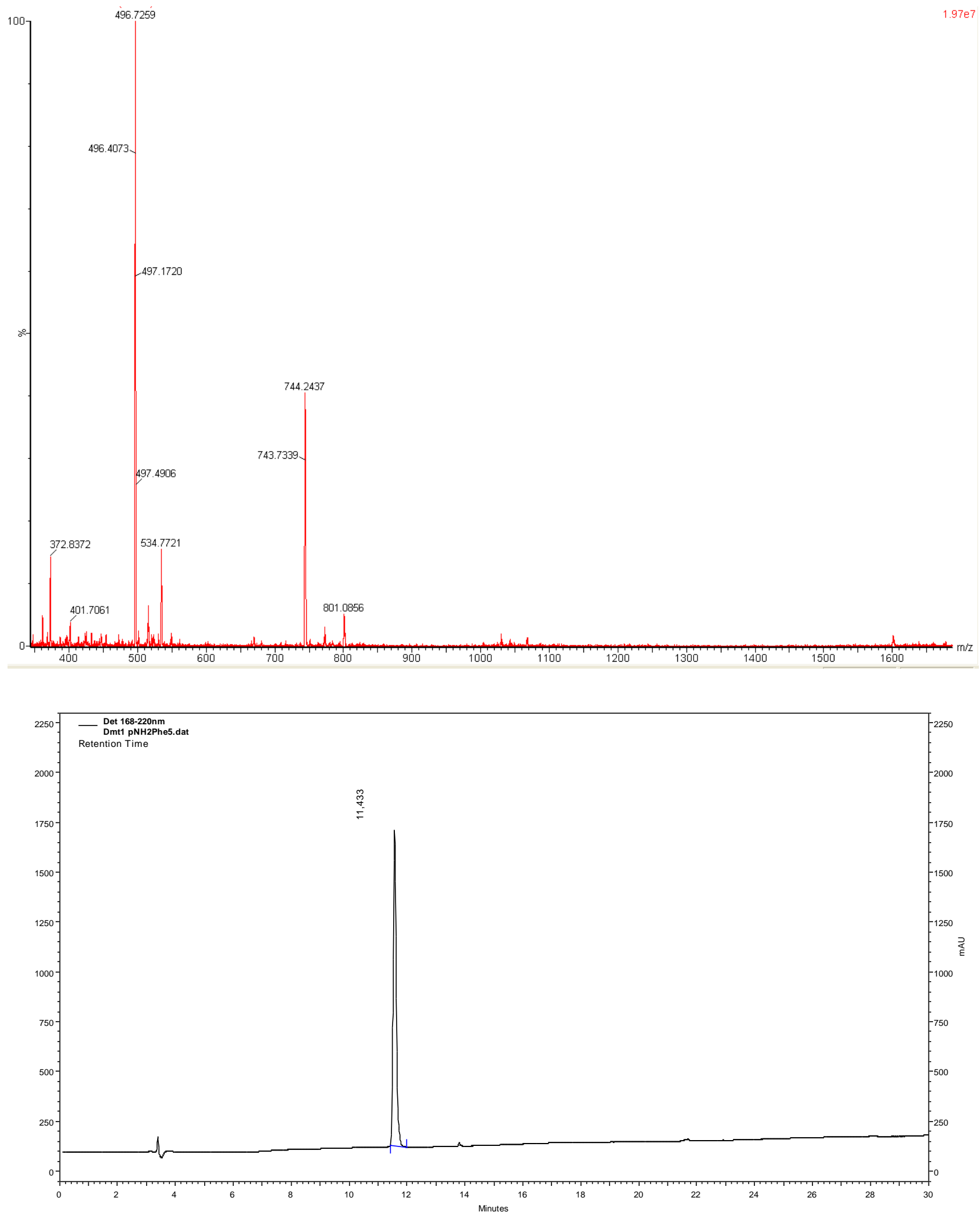


\section{$\left[\mathrm{Dmt}^{1,5}\right] \mathrm{N} / \mathrm{OFQ}(1-13) \mathrm{NH}_{2}$}
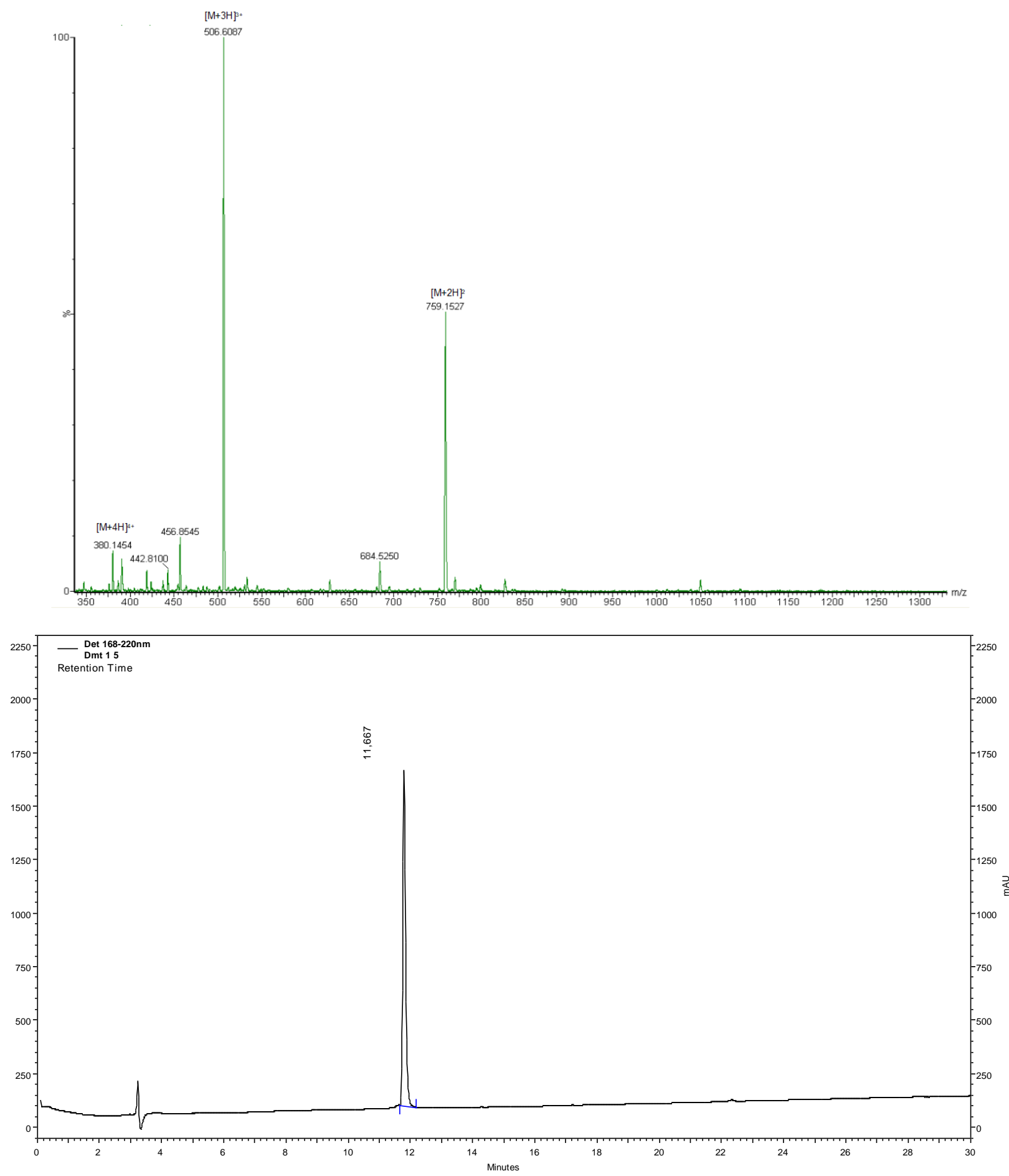


\section{MOLECULAR DYNAMICS}

Model set-up of non-natural peptides for MD. In order to perform MD simulation, the AMBER force field parameters and RESP atomic partial charges have been previously calculated for the nonnatural residue dimethyl tyrosine (Dmt), which is not included in the standard AMBER residue libraries. Force fields and connectivity parameters were built via the Antechamber, Prepgen, Parmchk and Tleap modules of the freely distributed AMBER package of programs (Ambertools). ${ }^{2}$ Calculations of the RESP atomic partial charges have been performed according to the method described by Cieplak et al., ${ }^{3}$ by first optimizing the structures and calculating a multi-conformation, multi-orientation QM electrostatic potential at the HF/6-31G* level for both the central fragment dipeptide $\left(\mathrm{Dmt}^{5}\right)$ and the N-terminal one $\left(\mathrm{Dmt}^{1}\right)$. The ORCA 4.0.1 package ${ }^{4}$ was adopted for the QM calculations. Thereafter, Molden input files were generated by the ORCA module orca_2mkl for each calculated conformation and orientation, and used as input to the MULTIWFN program ${ }^{5}$ for the final average and extraction of the RESP partial atomic charges via a 2-stage protocol including charge and equivalence constraints at both stages.

The peptides N/OFQ(1-9)- $\mathrm{NH}_{2}$ and [Dmt $\left.{ }^{1} \mathrm{Dmt}^{5}\right] \mathrm{N} / \mathrm{OFQ}(1-9)-\mathrm{NH}_{2}$ were then built. The number of the aminoacids used to setup the peptides in the simulations (nine) is limited by the maximum number of torsions (32) that can be managed by the docking software.

Model set-up of the mu receptor. The initial structure of the mu receptor was set up starting from the $3.5 \AA$ resolution cryo-electron microscopy structure of the receptor bound to the agonist peptide DAMGO and a nucleotide-free $\mathrm{G}_{\mathrm{i}}$ protein (PDB code $\left.6 \mathrm{DDF}\right) .{ }^{6}$ Side-chain atoms missing in the reported structure due to structural disorder, were added and minimised "in vacuum" by using the "Modeller" and "Rotamer" modules in the Chimera UCSF package."

Model set-up of the peptide-mu receptor complexes. The N/OFQ(1-9)- $\mathrm{NH}_{2}$ and $\left[\mathrm{Dmt}^{1,5}\right] \mathrm{N} / \mathrm{OFQ}(1$ 9)- $\mathrm{NH}_{2}$ peptides were docked using a "multi-flexible" docking procedure into the mu receptor as follows: a $600 \mathrm{~ns}$ MD trajectory of the overall mu-DAMGO-Gi-Protein water membrane system was produced; about 30 representative frames have been extracted from this trajectory, by a clustering algorithm as previously described. ${ }^{8}$ These frames constitute the set of receptor conformations used in the docking procedure. The Smina program, ${ }^{9}$ a fork for the Autodock Vina software package, ${ }^{10,11}$ was used to extract binding poses according to three different scoring functions, namely "vina", "vinardo" and "ad4". All the non-amidic rotatable bonds within the peptides were allowed to rotate freely, whereas each one of the receptor conformations was considered rigid. The "exhaustiveness" parameter for a search space in 30x30x45 angs box was set to 24 . For each receptor conformation, several results are produced which are merged, refined, clustered and sorted automatically to produce the final result, i.e. a small number of "interesting poses" or modes (parameter num_modes=9), within 
an energy range of less than $3 \mathrm{kcal} / \mathrm{mol}$ (energy_range=3). Therefore, about 1000 "interesting poses" were produced adopting three scoring function and 30 receptor conformations for each peptide. All these results were combined with a consensus procedure allowing to select, after minimization and rescoring of the poses, the best one, according to either their average rank, or an exponential distribution function of their rank for each scoring function, as recently proposed. ${ }^{12}$

Analysis of molecular dynamics trajectories. Percentages of formation of hydrogen bonds, and $1^{\text {st }}$ and $2^{\text {nd }}$ order water bridges interactions along MD trajectories have been calculated by custom procedures using the MDAnalysis python library. ${ }^{13}$ Polar and hydrophobic interactions between peptides and receptor residues were modelled as average coordination numbers via a continuous, differentiable switching function:

$$
\text { strength }=n_{n p c}=\sum_{i j} \frac{1-\left(r_{i j} / r_{0}\right)^{a}}{1-\left(r_{i j} / r_{0}\right)^{b}}
$$

with the $i$ and $j$ indexes running over the interacting atoms within the peptide fragment of interest and those within a chosen receptor residue, with $0 \leq$ strength $\leq n_{i} n_{j}$ (where $n_{i}$ and $n_{j}$ are the total number of atoms of the peptide fragment and the receptor residue, respectively, able to make the chosen type of interaction). For hydrophobic interactions, only carbon atoms are considered, for polar interactions only oxygens and nitrogens. The same "strength" function was calculated for salt bridges, $\pi$-cation and $\pi-\pi$ interactions. In this case $n_{i}=n_{j}=1$ because virtual atoms are defined at the center of mass of aromatic rings or charged groups, hence $0 \leq$ strength $\leq 1$. For hydrophobic, salt bridges, $\pi$-cation and $\pi-\pi$ interactions $a=6, b=12$ and $\mathrm{r}_{0}=6 \AA, 5 \AA, 4 \AA, 5.5 \AA$ respectively, while for polar interactions $a=8$, $b=12, \mathrm{r}_{0}=2.5$. The chosen values of $\mathrm{r}_{0}$ account for the typical interaction distance plus thermal motion's amplitude (e.g. $\sim 4.5 \AA+\sim 1.5 \AA$ in the case of hydrophobic interactions). The Plumed package $^{14}$ was patched to the Gromacs engine to undergo this kind of analysis. These coordination numbers (one per residue of the binding site) can be calculated on single structures as well as averaged along trajectories.

Beyond the roughness of the approach used here to monitor $\pi-\pi$ and $\pi$-cation interactions (based only on the distances between c.o.m.), a careful characterization of them would require quantum mechanics. However it is known that classical molecular dynamics using fixed-charge force fields has been successfully applied to describe $\pi$-stacking in both parallel and T-shaped configurations; ${ }^{15,16}$ on the other hand $\pi$-cation interactions are considered a shortcoming of most of fixed-charge force fields and their mention in this article emerges only by "a posteriori" analysis of distances between positive charges and aromatic rings. 
Figure S1. Analysis of the 600ns MD trajectory of the mu receptor-DAMGO-Gi protein complex (starting structure from PDB code: 6DDF). A) RMSD plot of heavy atoms of DAMGO. Side frame: RMSD distribution of DAMGO. B) Fractions of the main conformations of DAMGO found by clustering. C) The three main conformations extracted.

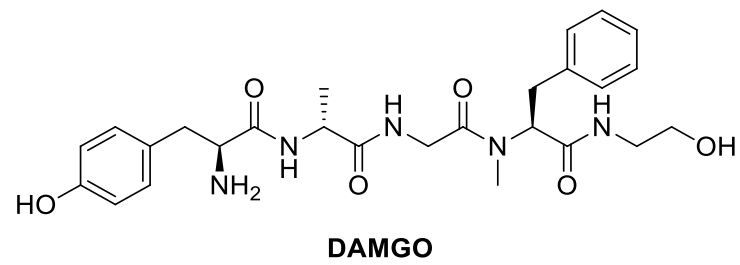

A)
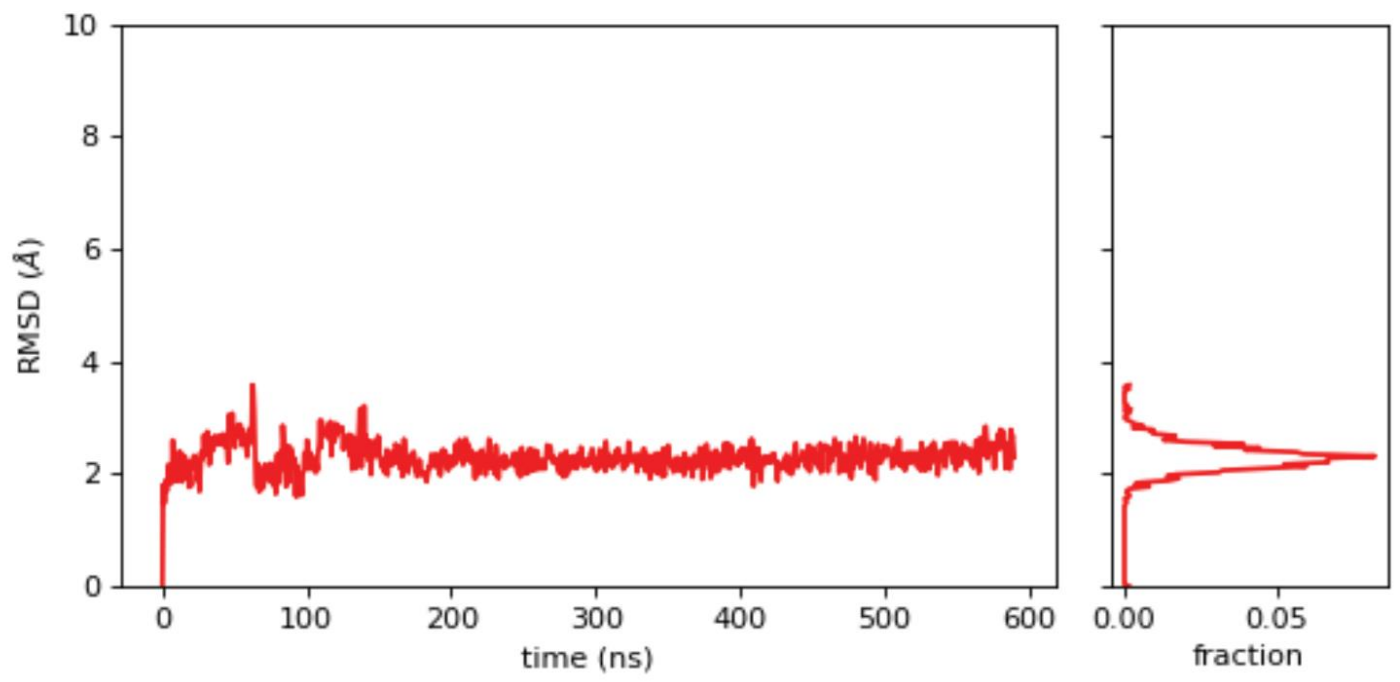

B)

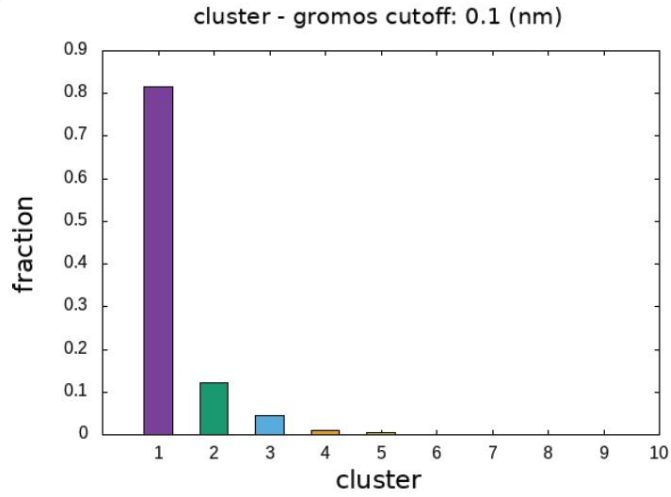

C)

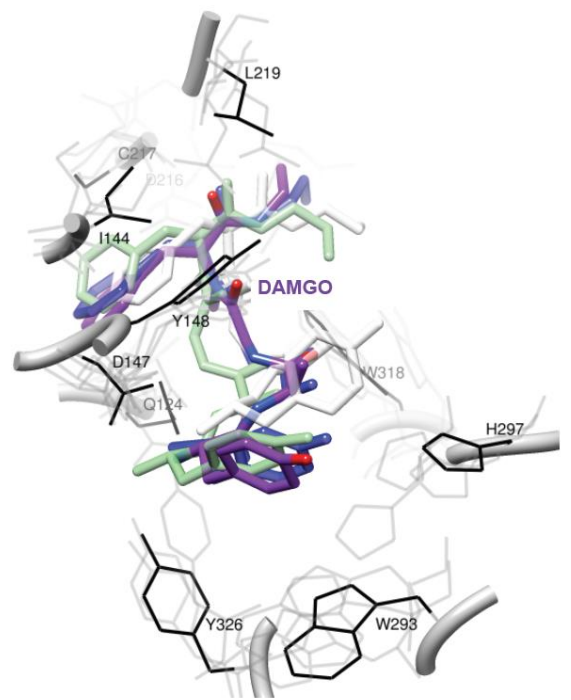


Figure S2. Analysis of the $2 \mathrm{MD}$ trajectories of the mu receptor-[Dmt $\left.{ }^{1,5}\right] \mathrm{N} / \mathrm{OFQ}(1-9)-\mathrm{NH}_{2}$ complex. A) RMSD plots of heavy atoms of residues 1-5 of the peptide. Side frames: RMSD distributions. B) Fractions of the main conformations found of the peptide by clustering. C) The three main conformations extracted.

A)
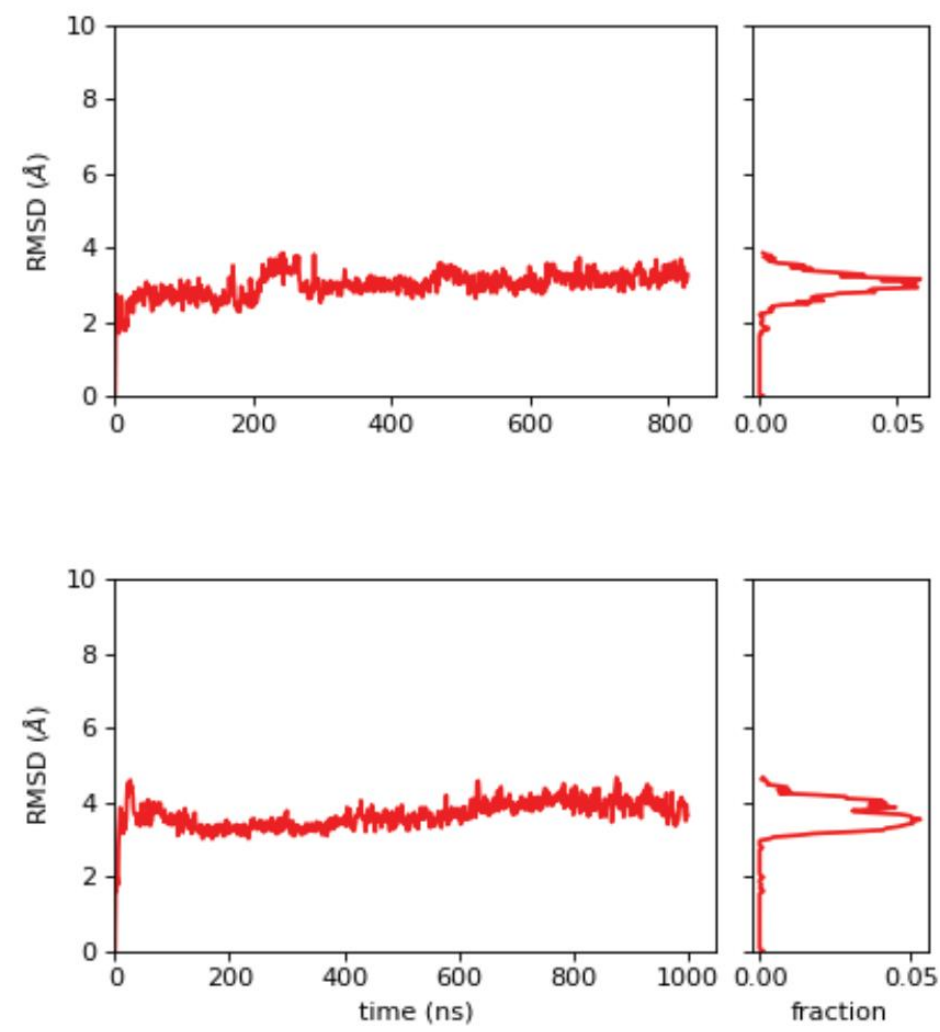

B

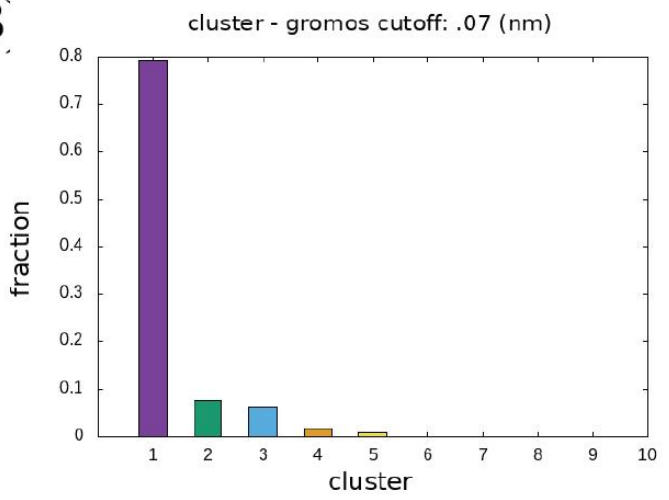

C)

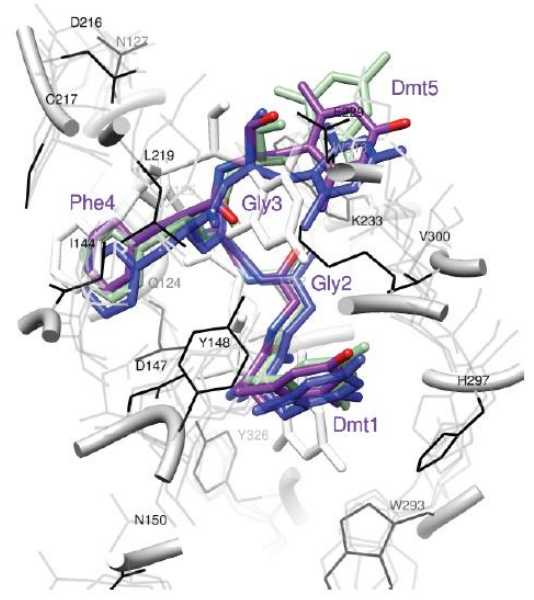


Figure S3. Analysis of the two MD trajectories of the N/OFQ(1-9)-NH2-mu receptor complex. A) RMSD plots of heavy atoms of residues 1-5 of N/OFQ(1-9)-NH2. Side frames: RMSD distributions. B) Fractions of the main conformations found for the peptide by clustering. C) The best conformation (purple) extracted compared with DAMGO (yellow).

A)
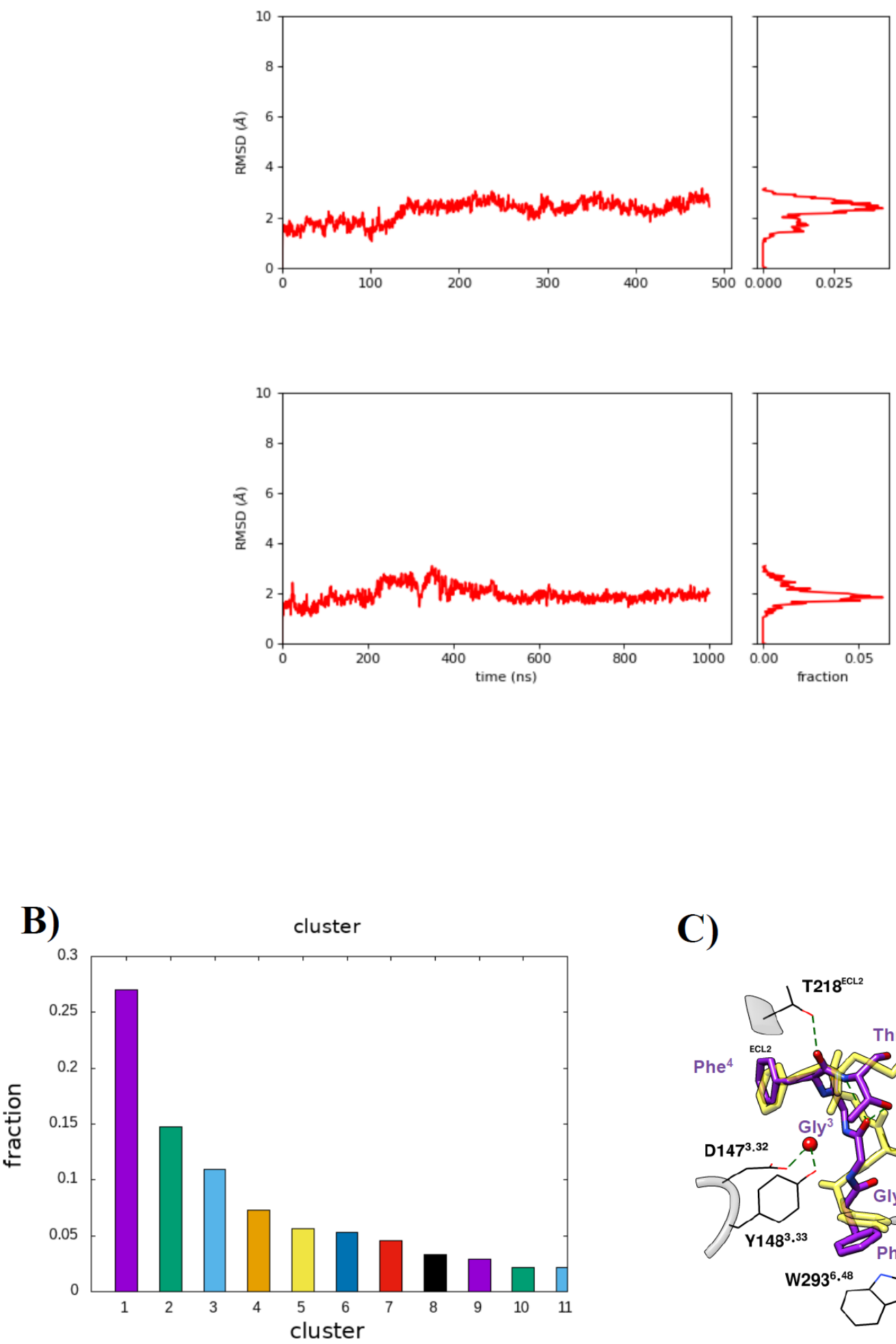

C)

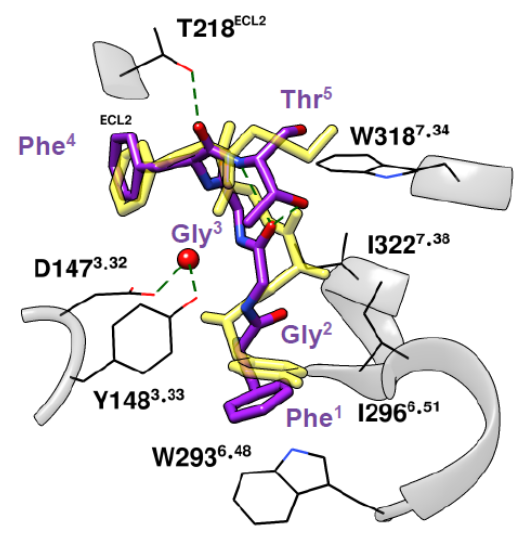




\section{REFERENCES}

1) Wang, X., Niu, S., Xu, L., Zhang, C., Meng, L., Zhang, X., Ma, D. Pd-Catalyzed Dimethylation of Tyrosine-Derived Picolinamide for Synthesis of (S)-N-Boc-2,6-dimethyltyrosine and Its Analogues. Org Lett 2017, 19, 246-249.

2) Case, D.A., I.Y. Ben-Shalom, S.R. Brozell, D.S. Cerutti, T.E. Cheatham, III, V.W.D. Cruzeiro, T.A. Darden, R.E. Duke, D. Ghoreishi, M.K. Gilson, H. Gohlke, A.W. Goetz, D. Greene, R Harris, N. Homeyer, S. Izadi, A. Kovalenko, T. Kurtzman, T.S. Lee, S. LeGrand, P. Li, C. Lin, J. Liu, T. Luchko, R. Luo, D.J. Mermelstein, K.M. Merz, Y. Miao, G. Monard, C. Nguyen, H. Nguyen, I. Omelyan, A. Onufriev, F. Pan, R. Qi, D.R. Roe, A. Roitberg, C. Sagui, S. Schott-Verdugo, J. Shen, C.L. Simmerling, J. Smith, R. Salomon-Ferrer, J. Swails, R.C. Walker, J. Wang, H. Wei, R.M. Wolf, X. Wu, L. Xiao, D.M. York and P.A. Kollman (2018), AMBER 2018, University of California, San Francisco.

3) Cieplak, P., W.D. Cornell, C. Bayly \& P.A. Kollman, Application of the multimolecule and multiconformational RESP methodology to biopolymers: Charge derivation for DNA, RNA, and proteins. J Comput Chem 1995, 16, 1357-1377.

4) Neese, F., The ORCA program system, Wires Computational Molecular Science, Wiley On line Library, 2011, https://doi.org/10.1002/wcms.81.

5) Lu, T., F. Chen, Multiwfn: A multifunctional wavefunction analyzer, J Comput Chem 2012, 33, 580592.

6) Koehl, A., H. Hu, S. Maeda, Y. Zhang, Q. Qu, J.M. Paggi, N.R. Latorraca, D. Hilger, R. Dawson, H. Matile, G.F.X. Schertler, S. Granier, W.I. Weis, R.O. Dror, A. Manglik, G. Skiniotis and B.K. Kobilka, Structure of the $\mu$-opioid receptor-Gi protein complex. Nature 2018, 558, 547-552.

7) Pettersen, E. F., Goddard, T. D.,Huang, C. C., Couch, G. S., Greenblatt, D. M., Meng, E. C., Ferrin, T. E., UCSF Chimera-a Visualization System for Exploratory Research and Analysis. J Comput Chem 2004, 25, 1605-1612.

8) Della Longa, S., Arcovito, A., Microswitches for the Activation of the Nociceptin Receptor Induced by Cebranopadol: Hints from Microsecond Molecular Dynamics, J Chem Inf Model 2019, 59, 818-831.

9) Koes, D.R., Baumgartner MP, Camacho CJ. Lessons learned in empirical scoring with smina from the CSAR 2011 benchmarking exercise. J Chem Inf Model 2013, 53, 1893-1904.

10) Morris, G. M., Huey, R., Lindstrom, W., Sanner, M. F., Belew, R. K., Goodsell, D. S., Olson, A. J., AutoDock4 and AutoDockTools4: Automated Docking with Selective Receptor Flexibility. J Comput Chem 2009, 30, 2785-2791.

11) Trott, O., Olson, A. J., AutoDock Vina: Improving the Speed and Accuracy of Docking with a New Scoring Function, Efficient Optimization, and Multithreading. J Comput Chem 2010, 31, 455-461.

12) Palacio-Rodríguez, K., Lans I, Cavasotto $C N$, Cossio $P$, Exponential consensus ranking improves the outcome in docking and receptor ensemble docking. Sci Rep 2019, 9, 5142.

13) Michaud-Agrawal, N., E. J. Denning, T. B. Woolf, and O. Beckstein. MDAnalysis: A Toolkit for the Analysis of Molecular Dynamics Simulations. J Comput Chem 2011, 32, 2319-2327.

14) Tribello, G. A., Bonomi, M., Branduardi, D., Camilloni, C., and Bussi, G. Plumed 2.0: new feathers for an old bird. Comput Phys Commun 2014, 185, 604-613.

15) Macias AT, MacKerell AD. $\mathrm{CH} /$ pi interactions involving aromatic amino acids: refinement of the CHARMM tryptophan forcefield. J Comput Chem 2005, 26, 1452-1463.

16) Kang M., Zhang P.,Cui H., and Loverde S.M. $\pi-\pi$ Stacking Mediated Chirality in Functional Supramolecular Filament. Macromolecules 2016, 49, 994-1001. 